\title{
Algal Supply System Design - Harmonized Version
}

Jared Abodeely

Daniel Stevens

Allison Ray

Kastli Schaller

Deborah Newby

March 2013

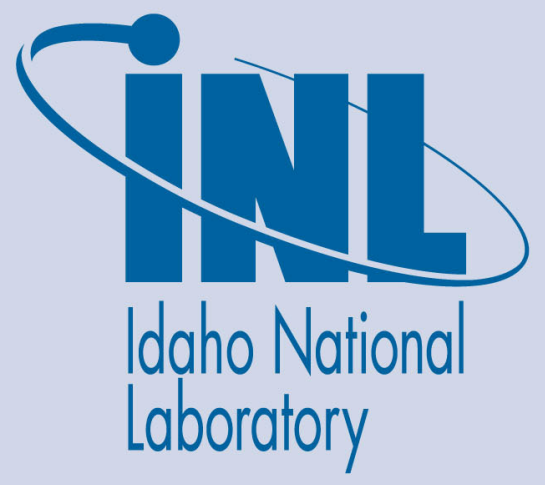

The INL is a U.S. Department of Energy National Laboratory operated by Battelle Energy Alliance 
INL/EXT-13-28890

\title{
Algal Supply System Design - Harmonized Version
}

\author{
Jared Abodeely \\ Daniel Stevens \\ Allison Ray \\ Kastli Schaller \\ Deborah Newby
}

March 2013

\section{Idaho National Laboratory \\ Idaho Falls, Idaho 83415}

http://www.inl.gov

Prepared for the

U.S. Department of Energy

Assistant Secretary for Energy Efficiency and Renewable Energy

Under DOE Idaho Operations Office

Contract DE-AC07-05ID14517 


\section{DISCLAIMER}

This information was prepared as an account of work sponsored by an agency of the U.S. Government. Neither the U.S. Government nor any agency thereof, nor any of their employees, makes any warranty, expressed or implied, or assumes any legal liability or responsibility for the accuracy, completeness, or usefulness, of any information, apparatus, product, or process disclosed, or represents that its use would not infringe privately owned rights. References herein to any specific commercial product, process, or service by trade name, trademark, manufacturer, or otherwise, does not necessarily constitute or imply its endorsement, recommendation, or favoring by the U.S. Government or any agency thereof. The views and opinions of authors expressed herein do not necessarily state or reflect those of the U.S. Government or any agency thereof. 


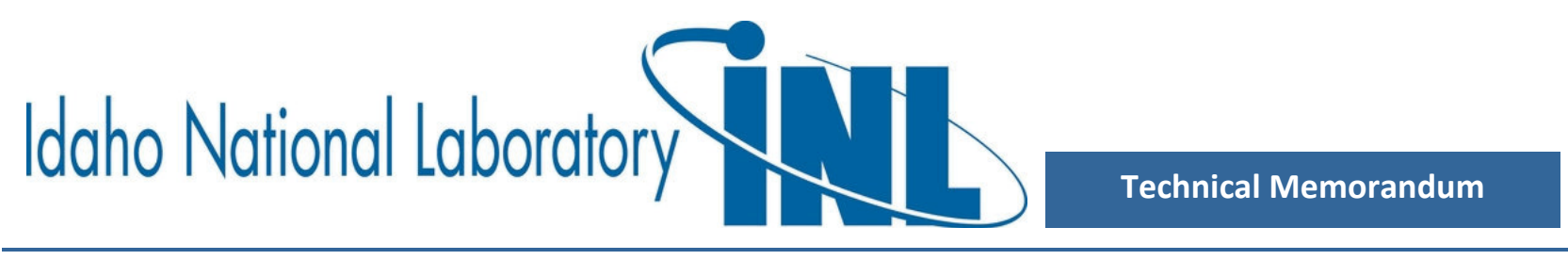

To:

Title: Algal Supply System Design-Harmonized Version

Authors: Jared Abodeely, Daniel Stevens, Allison Ray, Kastli Schaller, Deborah Newby

Platform:

Date: $\quad$ March 2013

Number: TM2013-002-0 INL/EXT-13-28890

\section{EXECUTIVE SUMMARY}

\section{Purpose and Scope}

The objective of this design report is to provide an assessment of current technologies used for production, dewatering, and converting microalgae cultivated in open-pond systems to biofuel. The original draft design was created in 2011 and has subsequently been brought into agreement with the DOE harmonized model. The design report extends beyond this harmonized model to discuss some of the challenges with assessing algal production systems, including the ability to (1) quickly assess alternative algal production system designs, (2) assess spatial and temporal variability, and (3) perform large-scale assessments considering multiple scenarios for thousands of potential sites. The Algae Logistics Model (ALM) was developed to address each of these limitations of current modeling efforts to enable assessment of the economic feasibility of algal production systems across the United States. The (ALM) enables (1) dynamic assessments using spatiotemporal conditions, (2) exploration of algal production system design configurations, (3) investigation of algal production system operating assumptions, and (4) trade-off assessments with technology decisions and operating assumptions. The report discusses results from the ALM, which is used to assess the baseline design determined by harmonization efforts between U.S. DOE national laboratories. Productivity and resource assessment data is provided by coupling the ALM with the Biomass Assessment Tool developed at PNNL. This high-fidelity data is dynamically passed to the ALM and used to help better understand the impacts of spatial and temporal constraints on algal production systems by providing a cost for producing extracted algal lipids annually for each potential site.

\section{Expected Outcome}

The expected outcome of the design report is to provide an update on current technologies and methods for cultivating, dewatering, and converting microalgae into biofuel. In addition, assessments of these technologies within an algal production system are performed using the ALM with data provided by the Biomass Assessment Tool. This computational modeling approach enables the ability to seamlessly integrate technologies being built across the BETO research platform and the broader research community while using high-fidelity data from each potential site to explore design configurations and 
operational assumptions that make biofuels produced from microalgae a viable option. The harmonized baseline design determined by the national laboratories serves as a starting point for exploring alternative algal production system designs and operation.

\section{Progress}

The previous algae design report was updated to discuss numerous technologies for cultivating, dewatering, and converting microalgae to biofuels. The harmonized baseline design for large-scale open-pond microalgae production systems is assessed using a computational approach that enables coupling of disparate datasets and models. Baseline performance and costs for algal production systems are characterized in terms of costs, material losses, and equipment performance. Several potential algal production sites are investigated to provide additional insight into the impacts of spatial and temporal variability on the cost of producing extracted algal lipids.

\section{Key Results}

See Design Report provided below. 


\section{CONTENTS}

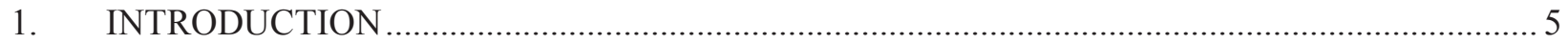

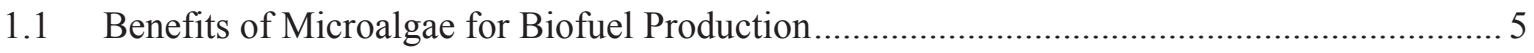

1.2 Challenges for Microalgae-Based Biofuels Development .................................................... 5

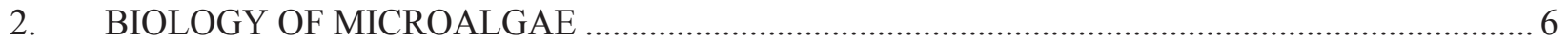

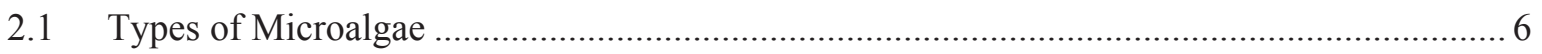

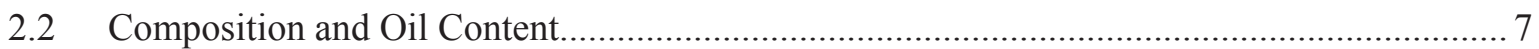

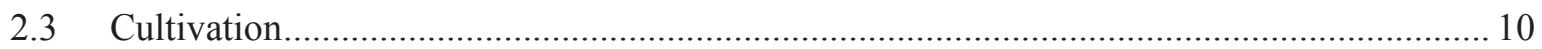

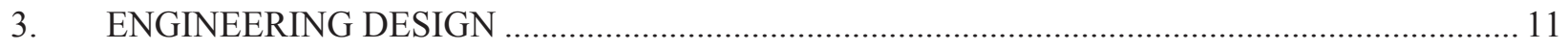

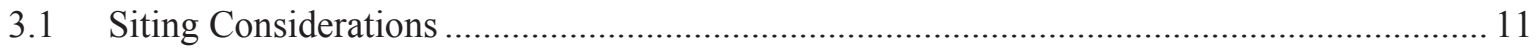

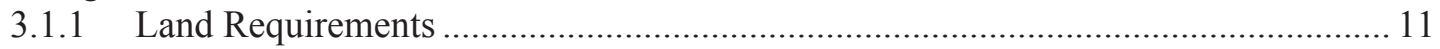

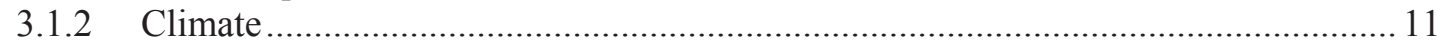

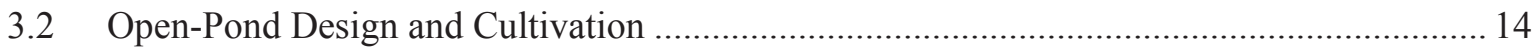

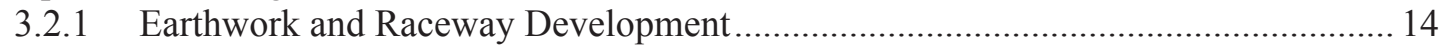

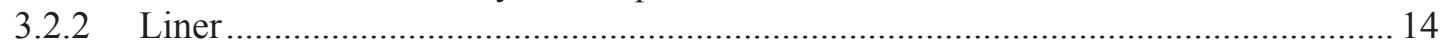

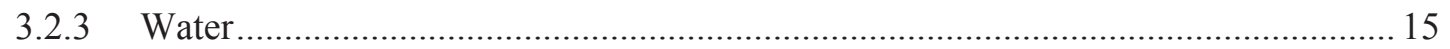

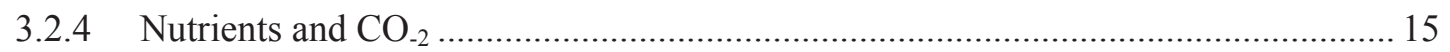

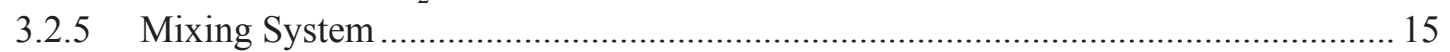

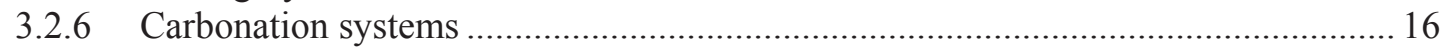

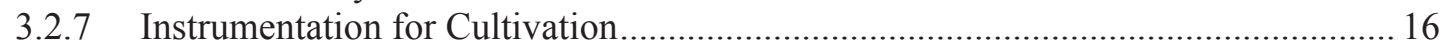

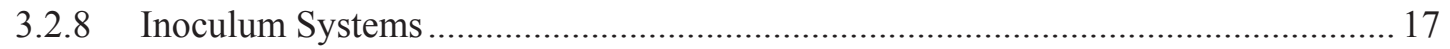

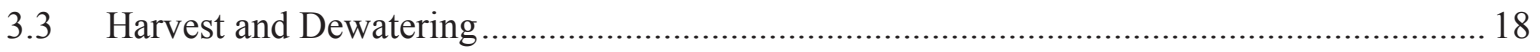

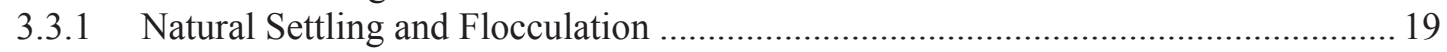

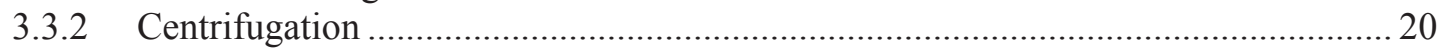

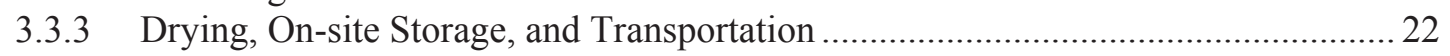

3.4 Conversion Pathways for Algal Biofuel Production......................................................... 25

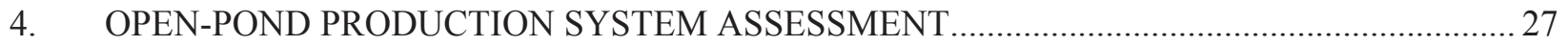

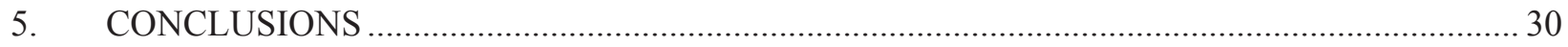

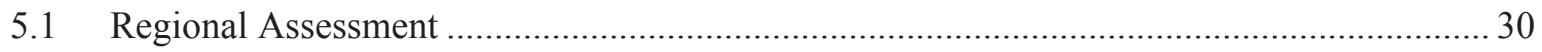

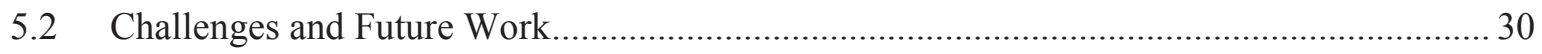

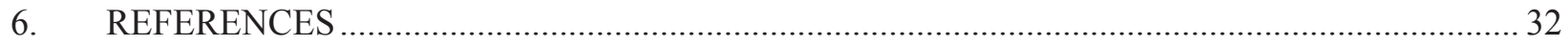

FIGURES

Figure 1. Green algae: Scenedesmus dimorphus (top left) and Chlorella sp. (top right); Diatoms, Cyclotella cryptica (bottom left) and Chaetoceros gracilis (bottom right)............................... 7

Figure 2. General chemical structure of lipids: top — triacylglycerides; bottom—phospholipid

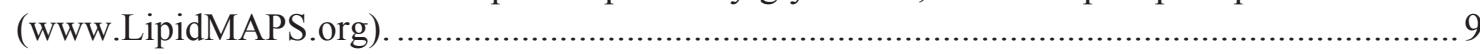

Figure 3. Potential microalgae farm sites in the conterminous United States (BAT assessment courtesy Pacific Northwest National Laboratory). ................................................................ 12

Figure 4. Regions inside the blue box with annual average temperatures above $15^{\circ} \mathrm{C}$ ideal for growing microalgae (Benneman 2008). 
Figure 5. Annual solar radiation average for the United States ........................................................... 13

Figure 6. Annual Average Horizontal Plane Pan Evaporation. ............................................................... 13

Figure 7. Example of pond construction $(<10$-acre ponds) (Pecos, TX) ............................................... 14

Figure 8. Example of a raceway paddle wheel system .................................................................... 16

Figure 9. Temperature/pH monitoring systems for algae cultivation. ................................................ 17

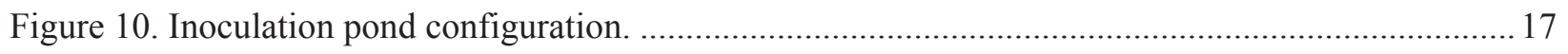

Figure 11. Dewatering techniques, filtration (A-1,2), flocculation (B-1,2), and centrifugation

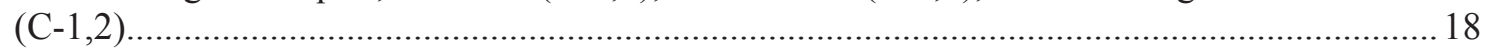

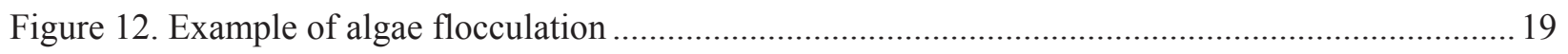

Figure 13. Qualitative costs associated with \% solids harvesting potential.........................................20

Figure 14. Cost assessment of the harmonized baseline design using high-fidelity productivity

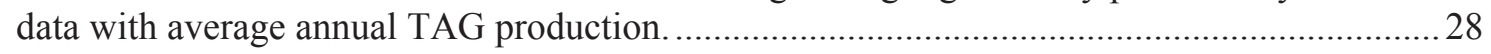

Figure 15. Cost comparison for alternative designs for the Tampa, FL site ...........................................29

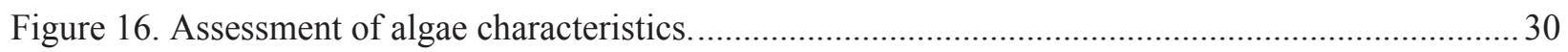

TABLES

Table 1. Lipid content and productivities of select microalgae species as adapted from Mata et al. (2010). 8

Table 2. Average biomass productivity for algae grown in outdoor ponds under nutrient-replete conditions, as adapted from Griffiths et al. (2009) .............................................................. 8

Table 3. Comparison of microalgae with other biodiesel feedstocks (DOE 2010).................................. 10

Table 4. Cultivation schemes with advantages and disadvantages (DOE 2010) ..................................... 10

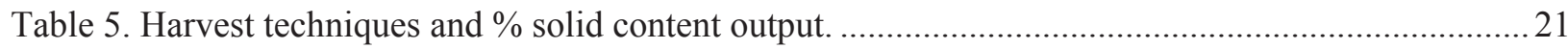

Table 6. Summary of drying methods available with their advantages and disadvantages as well as possible co-products and drying efficiency of algal biomass. .23

Table 7. Harmonized baseline design configuration with accompanying alternative design scenarios for the case study. 


\section{Algal Supply System Design-Harmonized Version}

\section{INTRODUCTION}

Increasing energy demands, diminishing petroleum reserves, growing dependence on foreign oil imports, and rising oil prices have fostered considerable interest in renewable fuels derived from biomass. The U.S. Energy Independence and Security Act of 2007 (EISA) expanded the Renewable Fuel Standard (RFS) requiring that U.S. transportation fuels contain a minimum of 36 billion gallons of renewable fuels by 2022, to include advanced and cellulosic biofuels and biodiesel derived from biomass. Algal biofuels have the potential to make a significant contribution to achieving these targets and moving the nation toward energy independence. The U.S. federal government invested $\$ 800 \mathrm{M}$ in biofuels research as part of the American Recovery and Renewal Act. Funds from this investment have been allocated to the Department of Energy (DOE) Office of Energy Efficiency and Renewable Energy's (EERE) Biomass Program to invest in research, development, and deployment of commercial-scale algae-to-biofuel processes (DOE 2010). A number of private companies are also making substantial investments in this area. This report presents the current state of technologies for cultivation, harvesting and dewatering, extraction, and conversion of microalgae to biofuels within an open-pond production system. Algal production systems are assessed based on the harmonized baseline with high-fidelity productivity and resource assessment data using dynamic methodologies to capture the spatial and temporal impacts on the feasibility of producing biofuels from microalgae.

\subsection{Benefits of Microalgae for Biofuel Production}

Biofuels, specifically biodiesel, derived from microalgae have received considerable interest as an alternative to conventional fossil fuels. Utilization of microalgae for biofuel production has the potential for additional benefits, including wastewater remediation, $\mathrm{CO}_{2}$ sequestration, and production of valuable co-products such as ethanol, methane, fertilizer, and livestock feed. Other benefits of microalgae in comparison with terrestrial feedstocks used for biofuels include high lipid content, growth versatility in various climates, high productivity, and use for fuel production is not directly competitive with food production such as was the case for other feedstocks (Wang et al. 2008). In addition, biodiesel produced from algal lipids has gained popularity because it is non-toxic, biodegradable, and produces significantly fewer emissions relative to diesel derived from petroleum sources (Bajpai and Tyagi 2006; Sheehan et al. 2000). Furthermore, algal biodiesel has enhanced cold-temperature performance, energy density, and storage stability compared to traditional petroleum fuels and has received considerable attention as an aviation fuel (Bruton et al. 2009).

\subsection{Challenges for Microalgae-Based Biofuels Development}

Major research and development challenges of algal biofuels include significant technology gaps in these areas: feedstock, infrastructure, harvest/dewatering, extraction, and conversion. For open-pond algal production systems, algal characteristics such as productivity, lipid content, and predator resistance are important attributes for creating high yielding, sustainable systems

Algal production system location and design are important for determining efficiency of nutrient and $\mathrm{CO}_{2}$ delivery and productivity. Co-location with wastewater and industrial facilities can provide accessible and inexpensive media, nutrients, and $\mathrm{CO}_{2}$ needed for cultivation, but co-location can also limit the siting of large-scale open-pond production systems. Typically co-location opportunities will be close to urban areas, raising both property costs and social concerns. As a result, other options for nutrient and $\mathrm{CO}_{2}$ supply must often be considered. With current technologies, harvest and dewatering is an energy intensive process for reducing moisture content to get the algae to a useable format. 
Most microalgae to biofuels processes, like algal biology, cultivation, harvesting/dewatering, extraction, and conversion are the focus of many R\&D projects being pursued by national laboratories, industry, and academia. Current challenges for producing biofuels from microalgae include:

- Production at a cost that is competitive with petroleum-based fuels poses considerable challenge to adoption of this technology

- Development of algal production technology is in the earliest stages

- Growth at commercial scale, in order to be successful, requires strain development

- Growth conditions that enable rapid growth of high-lipid producing strains that is inhibitory to competing organisms are needed

- Algal harvesting is estimated to consume 20-30\% of production costs (Gudin and Thepenier 1986)

- A huge challenge of harvesting algal biomass entails concentrating low-density cultures by as much as 1000-times for lipid extraction to be feasible

- Significant engineering-research efforts must be aimed at developing cost-effective algal harvesting (Pienkos and Darzins 2009)

- Nutrient recycle

- Credits for wastewater treatment and by-products.

\section{BIOLOGY OF MICROALGAE}

As mentioned previously, microalgae show significant promise as a biofuel feedstock. However their small size, diversity, and dilute concentrations even in growth ponds pose challenges. Thus, a basic understanding of microalgae is warranted. The following section describes the types of microalgae and some basic properties that may influence their growth, harvesting, and energy content. Microalgae are phototrophic eukaryotic microorganisms. They grow ubiquitously in the environment, in cold or hot climates, in lakes, streams, oceans, ice, and moist soil. They are photosynthetic, converting $\mathrm{CO}_{2}$ and light to $\mathrm{O}_{2}$ and simple sugars within membrane-bound organelles called chloroplasts. Microalgae are responsible for the origin of the $\mathrm{O}_{2}$ on Earth and nearly $50 \%$ of the global net primary production supporting life. They are unicellular but sometimes occur in colonies or aggregates of cells (Brock et al. 1994).

\subsection{Types of Microalgae}

There are three general types of unicellular algae: green, brown, and red.

Green algae belong to the group Chlorophyta and inhabit freshwater, marine, and moist terrestrial ecosystems. Even though their main carbon reserve is starch, they are known to produce large amounts of lipids under nutrient stress (Hu et al. 2008). Abundant lipid producers in the group Chlorophyta include Chlorella vulgaris and Chlorella protothecoides.

Brown algae belong to the group Chrysophyta and include diatoms that have lipid, not starch, as their carbon reserve and do not require nutrient stress to produce it. Organisms in the group Chrysophyta inhabit the same ecosystems as Clorophyta. Chaetoceros gracilis and Chaetoceros muelleri, two diatoms, are known to be excellent lipid producers. Figure 1 shows microscopic images of two green algae (Scenedesmus dimorphus and Chlorella sp.) and two diatoms (Cyclotella cryptica and Chaetoceros gracilis).

Lastly, red algae, which lack flagella, are less known for lipid production and belong to the group Rhodophyta. Some examples of red algae include Palmaria palmate and Coralline algae. They inhabit mainly marine ecosystems. 
Similar in appearance and found in many of the same environments, oxygenic phototrophs, cyanobacteria, are classified as prokaryotes; however they are still considered "algae" in some contexts. Cyanobacteria are generally more adaptable to extreme hot environments, such as hot springs, compared to algae (Brock et al. 1994). Cyanobacteria are also known to produce lipids.
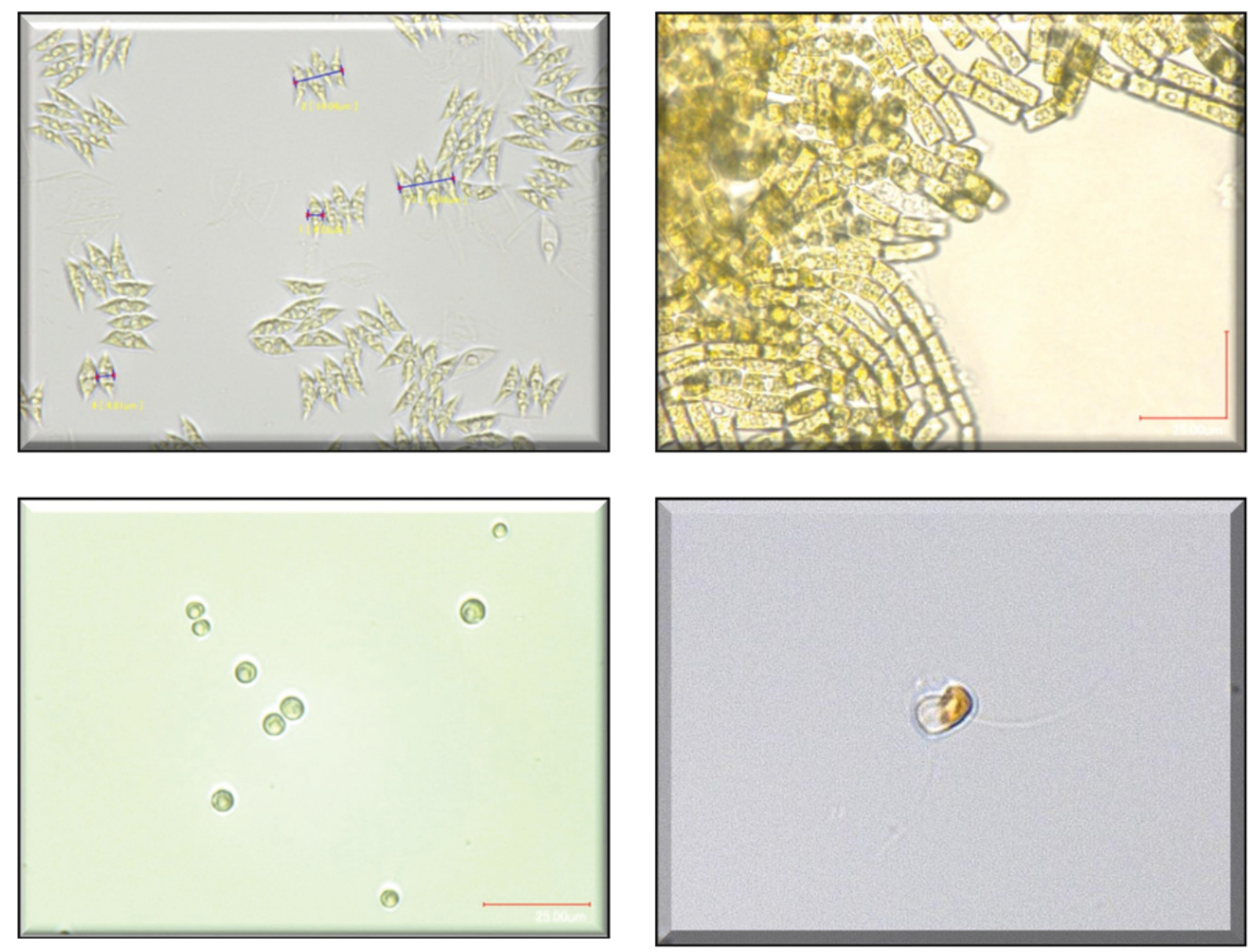

Figure 1. Green algae: Scenedesmus dimorphus (top left) and Chlorella sp. (top right); Diatoms, Cyclotella cryptica (bottom left) and Chaetoceros gracilis (bottom right).

\subsection{Composition and Oil Content}

Algae contain three major components: proteins, carbohydrates, and oils (lipids). Lipids have historically been the component of primary interest for biofuels production; however, algal components can be used for other valuable co-products as well, such as animal feed, pigments, fertilizers, poly-unsaturated fatty acids, and anti-oxidants (DOE 2010). Recently alternative conversion scenarios including hydrothermal liquefaction and pyrolysis, which capitalize on the energy content of the whole cells, have gained interest.

Some microalgae are known to produce large amounts of oil within their cellular structure. Lipid production depends on many factors such as growth (cell-division), temperature, $\mathrm{pH}$, salinity, and availability of micronutrients (Araujo et al. 2011). As reported in a review by Mata et al. (2010), the variability in lipid content of various algae is evident, but so is the growth production potential (Table 1). In some algal strains, increased lipid production occurs by stressing the organisms. Nutrient limitation, for 
example, is a key stressor for increased lipid production. Biomass productivity in outdoor ponds is presented in Table 2 and has been adapted from a review by Griffiths and Harrison (2009).

Table 1. Lipid content and productivities of select microalgae species as adapted from Mata et al. (2010).

\begin{tabular}{|l|c|c|}
\hline \multicolumn{1}{|c|}{ Microalgae Species } & $\begin{array}{c}\text { Lipid content } \\
\text { (\% dry weight biomass) }\end{array}$ & $\begin{array}{c}\text { Lipid productivity } \\
\text { (mg/L/day) }\end{array}$ \\
\hline Botryococcus braunii & $25.0-75.0$ & - \\
\hline Chaetoceros muelleri & 33.6 & 21.8 \\
\hline Chlorella protothecoides & $14.6-57.8$ & 1214 \\
\hline Chlorella vulgaris & $5.0-58.0$ & $11.2-40.0$ \\
\hline Chlorella sp. & $10.0-48.0$ & 42.1 \\
\hline Chlorococcum sp. & 19.3 & - \\
\hline Crypthecodinium cohnii & $20.0-51.5$ & 33.5 \\
\hline Dunaliella sp. & $17.5-67.0$ & $60.9-76.5$ \\
\hline Nannochloris sp. & $20.0-56.0$ & $84.0-142.0$ \\
\hline Nannochloropsis oculata & $22.7-29.7$ & $90.0-134.0$ \\
\hline Neochloris oleoabundans & $29.0-65.0$ & 34.8 \\
\hline Porphyridium cruentum & $9.0-18.8 / 60.7$ & $40.8-53.9$ \\
\hline Scenedesmus sp. & $19.6-21.1$ & \\
\hline
\end{tabular}

Table 2. Average biomass productivity for algae grown in outdoor ponds under nutrient-replete conditions, as adapted from Griffiths et al. (2009).

\begin{tabular}{|l|c|c|}
\hline \multicolumn{1}{|c|}{ Microalgae species } & $\begin{array}{c}\text { Biomass productivity } \\
\text { in outdoor ponds } \\
\left(\mathrm{g} \mathrm{m}^{-2} \text { day }^{-1}\right)\end{array}$ & $\begin{array}{c}\text { Ratio of Average } \\
\text { Biomass Productivity } \\
\text { (Outdoor pond prod./Laboratory prod.) }\end{array}$ \\
\hline Amphora & 39 & 0.98 \\
\hline Chlorella pyrenoidosa & 26 & - \\
\hline Chlorella vulgaris & 14 & 1.49 \\
\hline Cyclotella cryptica & 16 & 2.44 \\
\hline Isochrysis galbana & 27 & 1.76 \\
\hline Nannochloropsis & 28 & \\
\hline Nannochloropsis salina & 15 & 0.44 \\
\hline Scenedesmus obliquus & 25 & 0.68 \\
\hline Spirulina platensis & 48 & 1.30 \\
\hline Tetraselmis suecica & 11 & \\
\hline Average productivity & 19 & \\
\hline
\end{tabular}


Lipids are abundant in many algae. Lipids and fatty acids serve as key components for cell membranes in plants and algae as well as being important for chemical signaling and energy storage (Ekman et al. 2007). Environmental factors such as temperature, light cycles, and nutrient deprivation can influence the capacity for lipid synthesis (Roessler 1988; Shirffrin and Chisholm 1981; Sukenik et al. 1989). During optimal conditions, fatty acid synthesis in algal cells is primarily for membrane lipids.

Under conditions of stress, most algae alter their lipid production pathway to manufacture neutral lipids. In most stress conditions that induce lipid synthesis, photosynthetic activity decreases causing a slowed growth rate (Shirffrin and Chisholm 1981). It has also been noted in Nannochloropsis sp., that lipids produced during the day are subsequently consumed as energy for cell division during the dark cycle (Sukenik et al. 1989). Lipid and fatty acid composition can reach well over 50\% of the cellular dry weight of an algal cell with neutral lipids accounting for up to $80 \%$ of the total lipids, as in the case with Neochloris oleoabundans (Tornabene et al. 1983).

Microalgae can manufacture a variety of lipids that can include, tri, di-, and monoglycerides, phospho- and glycolipids, and other hydrocarbons (Banerjee et al. 2002; Chisti 2007) (Figure 2). Fatty acid composition varies depending on species but common fatty acids can include palmitic, linolenic, linoleic, and oleic (Ben-Amotz et al. 1985; Tornabene et al. 1982; Tornabene et al. 1983).

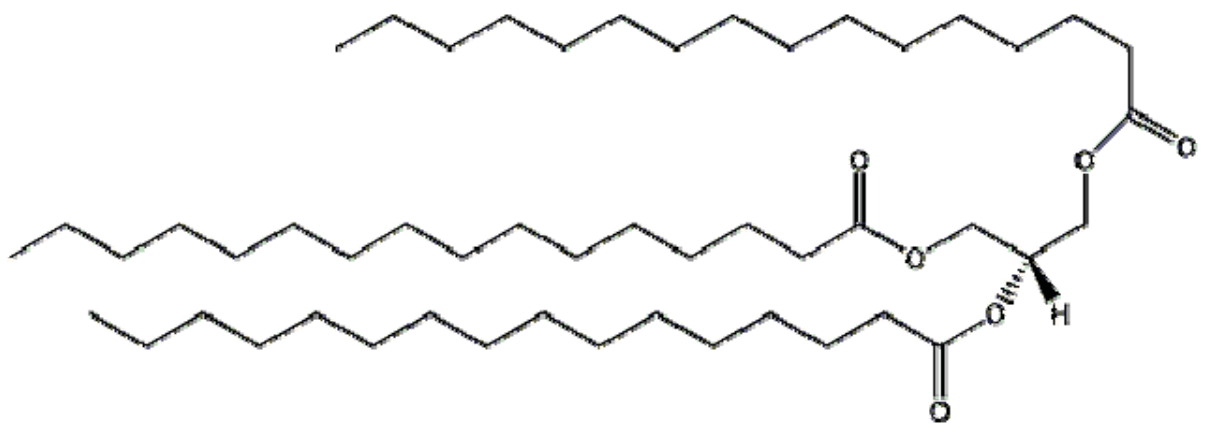

Tripalmitin: Triacyleglyceride

Common Name: TG (16:0/16:0/16:0)

Systematic Name: 1,2,3-trihexadecanoyl-glycerol

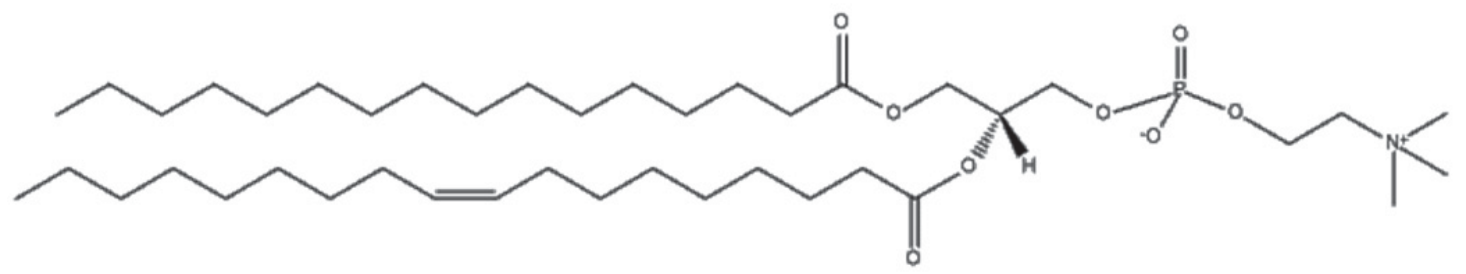

Phospholipid

Common Name: PC (16:0/18:1(9Z))

Systematic Name: 1-hexadecanoyl-2-(9Z-octadecenoyl)-sn-glycero-3-phosphocholine

Figure 2. General chemical structure of lipids: top — triacylglycerides; bottom—phospholipid (www.LipidMAPS.org). 
Depending on their chemical characteristics, lipids can be generalized into two different classes, polar and non-polar (neutral) (Christie 2003; Greenwell et al. 2010). Polar lipids can include phospholipids and glycolipids. Neutral lipids can include tri-, di-, and monoglycerides.

A major fuel constituent called triacyglycerols (TAG), a neutral storage lipid, is composed of fatty acids synthesized in the stroma of plastids. The environment and strain of algae may determine the pathway of TAG synthesis in the cell. Fatty acids, usually 16 to 18 carbon chains, are transferred to a glycerol molecule by acyl transfers via the intermediate diacylglycerol (DAG) (Athenstaedt and Daum 2006; DOE 2010; Lung and Weselake 2006).

\subsection{Cultivation}

Algae have the potential to produce greater amounts of biomass and lipids per acre than any terrestrial biomass (Table 3). Furthermore, it can be cultivated on marginal lands and not compete with food crops.

Algae can be grown phototrophically using sunlight or artificial light, or heterotrophically without light using simple sugars as a carbon source. Photoautotrophic cultivation can occur in open pond systems or closed photobioreactor systems. Open-pond systems require less capital expense compared to closed photobioreactor systems; however, daily productivity per liter typically is less. Table 4 below lists the two types of cultivation and their advantages and disadvantages.

Table 3. Comparison of microalgae with other biodiesel feedstocks (DOE 2010).

\begin{tabular}{|l|c|c|}
\hline \multicolumn{1}{|c|}{ Crop } & $\begin{array}{c}\text { Oil yield } \\
\text { (gal oil/acre/year) }\end{array}$ & $\begin{array}{c}\text { Land area required } \\
\text { (million acre) }\end{array}$ \\
\hline Soybean & 48 & 833 \\
\hline Camelina & 62 & - \\
\hline Sunflower & 102 & - \\
\hline Canola & 127 & 315 \\
\hline Jatropha & 202 & 198 \\
\hline Palm oil & 635 & 63 \\
\hline Microalgae & $1,000-6,500$ & 37 \\
\hline
\end{tabular}

Table 4. Cultivation schemes with advantages and disadvantages (DOE 2010).

\begin{tabular}{|c|c|c|c|}
\hline & & Advantages & Disadvantages \\
\hline \multirow{2}{*}{$\begin{array}{l}\text { Photoautotrophic } \\
\text { Cultivation }\end{array}$} & $\begin{array}{l}\text { Closed } \\
\text { PBRs }\end{array}$ & $\begin{array}{l}\text { Less water loss than open pond } \\
\text { Superior long-term culture maintenance } \\
\text { Higher surface-to-volume ratio can } \\
\text { support higher volumetric cell densities }\end{array}$ & $\begin{array}{l}\text { Scalability challenges } \\
\text { Requires temperature maintenance (no } \\
\text { evaporative cooling) } \\
\text { Biofilm formation may necessitate } \\
\text { periodic cleaning } \\
\text { Requires maximum light exposure }\end{array}$ \\
\hline & $\begin{array}{l}\text { Open } \\
\text { Pond }\end{array}$ & $\begin{array}{l}\text { Evaporative cooling maintains } \\
\text { temperature } \\
\text { Lower capital costs } \\
\text { Larger volume (capacity) }\end{array}$ & $\begin{array}{l}\text { Subject to daily and seasonal changes } \\
\text { in temperature and humidity } \\
\text { Inherently difficult to maintain } \\
\text { monocultures } \\
\text { Need maximum light exposure }\end{array}$ \\
\hline \multicolumn{2}{|c|}{ Heterotrophic Cultivation } & $\begin{array}{l}\text { Easier to maintain optimal conditions } \\
\text { for production and contamination } \\
\text { prevention } \\
\text { Opportunity to use inexpensive } \\
\text { lignocellulosic sugars for growth } \\
\text { Achieves high biomass concentrations }\end{array}$ & $\begin{array}{l}\text { Cost and availability of suitable } \\
\text { feedstocks such as lignocellulosic } \\
\text { sugars } \\
\text { Competes with other biofuel } \\
\text { technologies for feedstocks }\end{array}$ \\
\hline
\end{tabular}




\section{ENGINEERING DESIGN}

Design of open-pond algal production systems must consider the algal strain, productivity potential, and capacity when selecting a site. These factors will influence the scale and methods utilized for producing the most economically feasible biofuel. This section describes siting criteria for open-pond algal production systems and current methods that can be utilized within the processes necessary to create biofuels from microalgae.

\subsection{Siting Considerations}

When siting an algae open-pond system, several key site characteristics have to be considered including the topography, climate, resource availability, and local incentives. These site characteristics have a significant impact on the cost of building the unit farm and cultivating the algae.

\subsubsection{Land Requirements}

Selection of land resources is a key component to the viability of open-pond microalgae production systems. Land characteristics have to be considered for development and economic feasibility. Given the size of the unit farms under consideration, land with minimum slope variation is needed to reduce the amount of earthwork. Slopes ranging from $0-10 \%$ have been considered in several land assessments found in literature (Benemann et al. 1982; Lundquist et al. 2010).

Additional criteria for potential open-pond microalgae production systems sites is that the land should be noncompetitive, non-sensitive, and sparsely populated. Excluded sites may include land currently used for agricultural purposes, open water, urban areas, airports, state and national parks, wildlife refuges, and other environmentally sensitive locations. Over 11,500 sites were identified that meet a $1 \%$ slope and land- use requirement criteria equating to over $5 \%$ of the conterminous United States that may be available according to a recent study (Figure 3) (Wigmosta et al. 2011). However, placement of open-pond microalgae production systems near urban areas has potential benefits because of the use of wastewater and industrial and commercial process wastes that can provide nutrients and $\mathrm{CO}_{2}$ for algae cultivation. Land value is typically higher near these urban areas, so additional economic evaluations need to be completed to assess the potential benefits of collocation vs. lower land costs.

In addition to slope, soil composition and depth are important to the design of the open-pond microalgae farms. Soil composition will determine whether compacted soil can be used to line the ponds without permeability concerns. Soils with high clay and silt content are less permeable, reducing water loss and soil degradation potential. The ponds also tend to be self-sealing as some of the algae settles. Sites that have sandy or gravel compositions will either need clay brought in to seal the bottom of the pond or a synthetic liner, both of which would incur additional costs. Sufficient earth depth at a selected site is important for stabilizing the foundation of the pond. Ponds are generally excavated to allow the surface of the pond to near or above the ground level. Ponds that are built above ground need excavation only for the sump area (Benemann et al. 1982). Soil composition and depth were not considered in siting the potential farms presented in Figure 3 but may be considered in future assessments to help identify design needs for a specific location.

\subsubsection{Climate}

The climate and weather patterns around a site have a significant impact on annual algal production. The seasonal variation, number of abundant radiation days, and weather conditions account for daily productivity variation and in extreme cases (i.e., hurricanes, tornadoes, etc.) may crash the entire production system. In general, microalgae are cultivated in warmer regions of the globe. Figure 4 shows ideal locations for growing algae based on temperature. Regions inside the blue box have annual average temperatures above $15^{\circ} \mathrm{C}$. Regions outside this area may require additional $\mathrm{R} \& \mathrm{D}$ to help develop psychrophilic algal strains that could be cultivated at much lower temperature. Figure 5 shows the annual average solar radiation for the United States. It can be seen that the Southwest United States has the 
greatest potential for cultivating microalgae based on temperature and solar radiation but additional factors such as water requirements must also be considered.

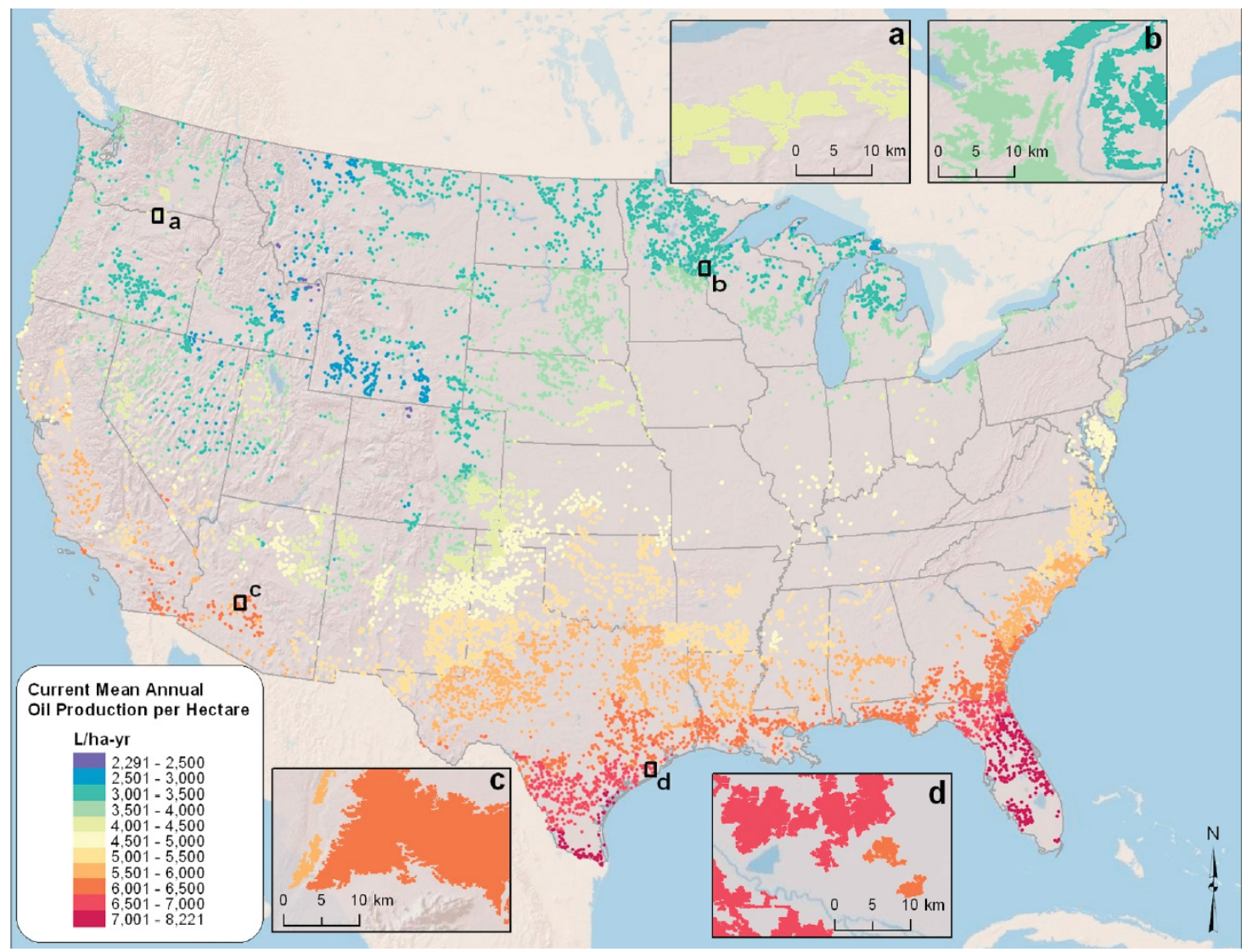

Figure 3. Potential microalgae farm sites in the conterminous United States (BAT assessment courtesy Pacific Northwest National Laboratory).

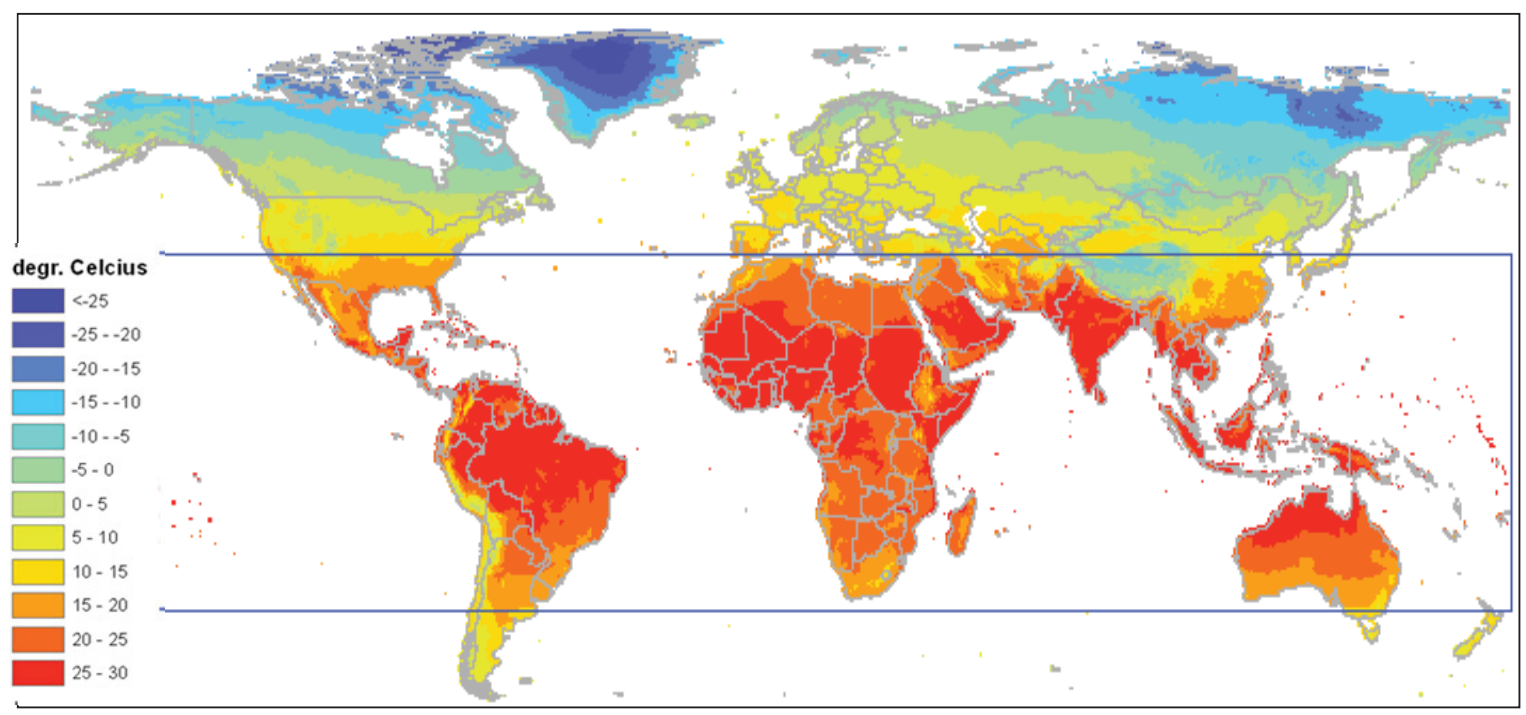

Figure 4. Regions inside the blue box with annual average temperatures above $15^{\circ} \mathrm{C}$ ideal for growing microalgae (Benneman 2008). 
Water resource availability is one of the key challenges in development of the algal biofuels industry. Large scale algal production systems require a substantial amount of water and in some parts of the United States may compete against social and agricultural uses. One of the reasons for the large amounts of water use is daily evaporation (Figure 6). Evaporation can vary significantly spatially and temporally. Precipitation can help mitigate losses due to evaporation but in most locations does not offset the total annual losses.

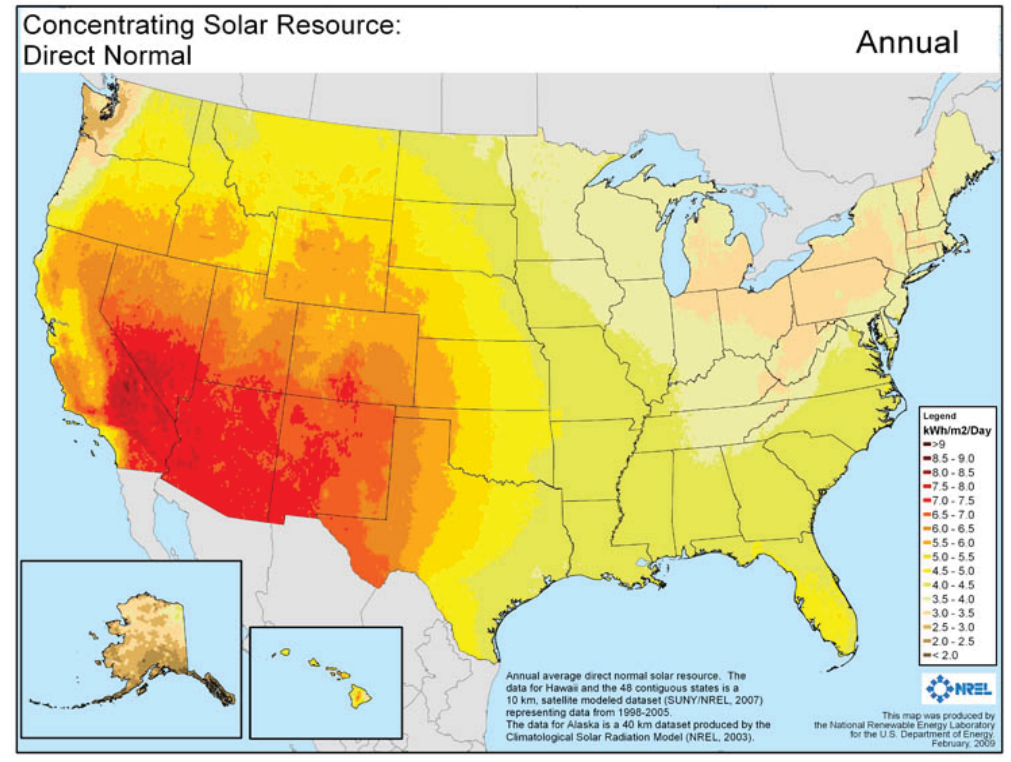

Figure 5. Annual solar radiation average for the United States (http://www.nrel.gov/gis/images/map_csp_us_10km_annual_fe b2009.jpg).

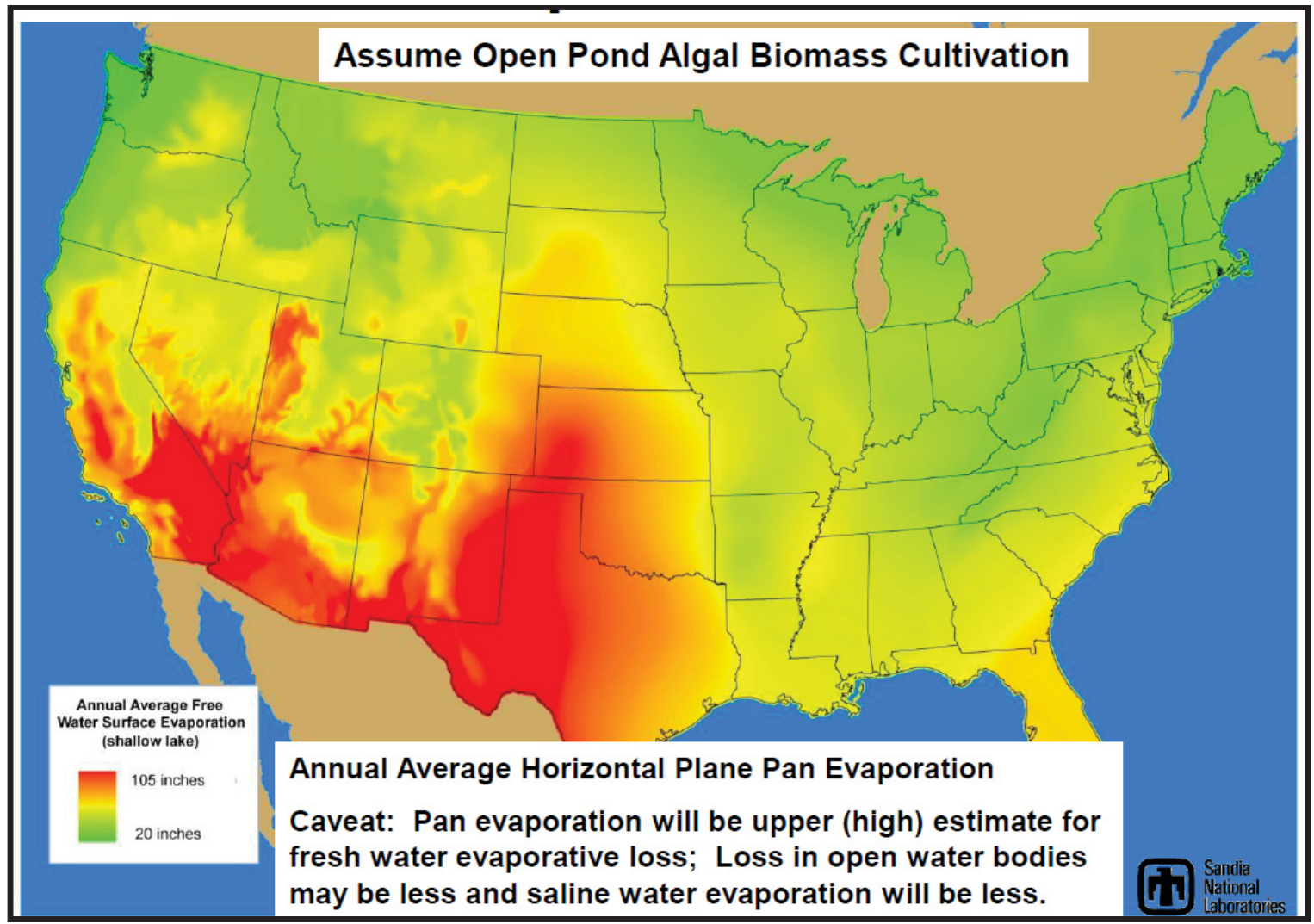

Figure 6. Annual Average Horizontal Plane Pan Evaporation.

(http://www.wind-sea-algae.org/wsapresentations/day1/Ron\%20Pate\%20WSA\%20April\%202009.pdf). 


\subsection{Open-Pond Design and Cultivation}

Open-pond algal production system raceway design elements include earthwork, infrastructure, resource (nutrients and $\mathrm{CO}_{2}$ ) delivery, and inoculum delivery mechanisms. Large-scale algal production systems will likely require a certain amount of earthwork to meet the needs of the raceway design criteria and configuration. Raceways are equipped with a paddle wheel and aeration system to prevent settling, allow adequate movement for light absorption, and enhance mixing of nutrients and $\mathrm{CO}_{2}$ with the media (Figure 7). Vertical resource storage containers house and operate as staging areas for nutrient and $\mathrm{CO}_{2}$ delivery. Instrumentation systems are coupled to each raceway to enable monitoring of key production factors such as nutrient and $\mathrm{CO}_{2}$ levels, $\mathrm{pH}$ levels, and temperature. Smaller inoculum ponds are also integrated into general designs, providing a continuous flow of culture to the larger production ponds.
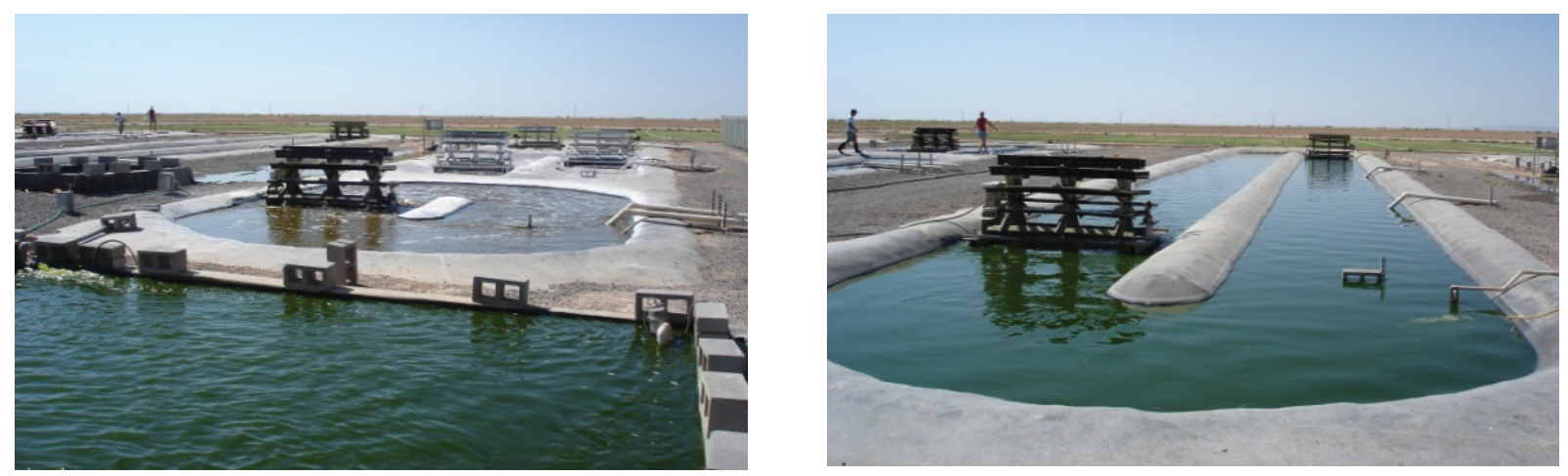

Figure 7. Example of pond construction ( $<10$-acre ponds) (Pecos, TX).

\subsubsection{Earthwork and Raceway Development}

For large-scale algal production systems, earthwork will be required to enable the raceway configuration optimal for production. Landscapes with minimal slopes like those identified in Figure 3 provide an opportunity to reduce the amount of earthwork needed resulting in reduced costs. Additional earthwork can include digging out the raceways and building berms around the raceways for wind abatement and pest control.

In addition to earthworks, raceways can be built using concrete blocks for walls and berms with clay or high density polyethylene (HDPE) pond liner for leaching protection. The concrete blocks can be used to reduce erosion of the pond edges and strengthen the raceway structure. In certain areas where a hardened clay material (south-southwest) is available, this may replace the addition of concrete blocks around the periphery of the raceway. In locations where lava rock or gravel rock are readily available and inexpensive, these may be used to help strengthen the pond wall. It should be understood however that the above configurations represent various alternatives for engineering designs for pond construction and do not necessarily represent the best case scenario for pond construction.

\subsubsection{Liner}

Liners may be added to the pond system to maintain the integrity of the culture and restrict leaching. There are several options available when selecting a pond liner. Pond liner that includes polyvinyl chloride (PVC), high-density polyethylene (HDPE), and ethylene propylene diene monomer (EPDM) are available in a variety of configurations. The use of a pond liner adds significant costs but benefits can be significant. The liners are easier to clean than rock or clay liners which can decrease contamination compared to something like clay. The likelihood of pond liners allowing leaching of raceway contents into the deeper earth layer are potentially less than that of clay or crushed rock. Costs of the liner do depend on the type of pond liner and its thickness. The availability of pond liner in most areas is very high compared to other options for the pond base. Crushed rock is another option for pond lining but is also expensive and less effective (Lundquist et al. 2010; Weissman and Goebel 1987). Although mass 
produced pond liner is not the best solution, further exploration of new options for lining ponds is needed. Another liner option, harden clay, which is used for wastewater settling ponds is relatively inexpensive compared to other liners available. In some situations where clay is locally available and approved for use with wastewater and algae growth, this option lowers costs significantly.

\subsubsection{Water}

Water is essential for algae cultivation. To provide the algae cultures with enough water for adequate growth, a water source or sources is needed near the designated site that is capable of maintaining a water supply based on the capacity of the algal production system. Previous reports assume water from local reserves (lakes/aquifers), municipal wastewater facilities, saline lakes, and oceans (Benemann 1980; Benemann and Oswald 1996; Lundquist et al. 2010; Weissman and Goebel 1987). Most water reserves have a cost associated with their use, transport, or pumping. Water from waste streams is unique in that nutrients from these streams can also be used by the algae for growth. As discussed below, evaporative and blowdown losses need to be replenished by a water stream. Depending on siting, water can be used from wastewater streams when the farm is located near a municipal facility and from local reserves (wells/lakes/aquifers) when wastewater is not available. Saline water sources are a viable source of water and nutrients to support growth but are species-specific and may not be available in most locations.

Water from settling basins and harvesting steps will be recycled back to the cultivation ponds. In some reports, water costs are not evaluated or factored into the economics of algae farm development. Water does represent cost into the system but is a component that can be recycled and used in a variety of capacities. Reusable water from flocculation and centrifugation steps can be pumped directly back to cultivation ponds or a clarifying tank to be cleaned and used in the inoculation ponds.

\subsubsection{Nutrients and $\mathrm{CO}_{-2}$}

Nutrient and carbon requirements for algae may be provided by chemicals purchased in bulk. Wastewater effluent from municipal wastewater treatment facilities can also provide nutrients needed for algae cultivation with supplementation from commercial chemicals. Recently, anhydrous ammonia and diammonium phosphate (DAP) were suggested as sources for nitrogen and DAP, respectively (ANL et al. 2012).

For additional supplemental nutrients, fertilizer-enriched irrigation runoff from farms can also be used. In addition to irrigation runoff, wastewater can be processed from wastewater processing plants and then directly pumped into the raceway to supply water and nutrients. The solids can provide organic carbon as well as other nutrients for culture growth. Another carbon source, $\mathrm{CO}_{2}$ contained in flue gas from power plants/factories, can be used for carbon supplementation and to increase growth of the algae. The carbon source from plant effluent and supplemental $\mathrm{CO}_{2}$ generated from onsite processes (e.g., anaerobic digestion) can be supplied by a central low-pressure pipeline that is directed to each growth pond. In open- pond designs, nutrients and water are mixed as they enter the growth ponds.

\subsubsection{Mixing System}

Pond mixing can be accomplished by current state of technology paddle wheels designed for raceway ponds. Culture mixing is important to allow the algal cells to move in and out of the light zone for photosynthesis. Large 10-acre (4-ha) ponds can be mixed by paddle wheels at speeds of roughly $20-30 \mathrm{~cm} / \mathrm{sec}$ (Figure 8). Although paddle wheel mixing is the most common mixing mechanism, mixing designs such as pump mixing, jet mixer, air-lift mixing, and others have been used. Although there are mixing variations, mixing velocity is an essential detail in reducing energy consumption and creating an ideal residence time for the culture growth. Considerations for the number of paddle wheels for each pond are calculated on the dimensions of the channels. Inoculation ponds that use paddle wheels will require smaller and fewer units per pond than larger 4-ha ponds. Mixing systems for flocculation stations will use centrifugal pumps to maintain efficient contact of floc to algae. Energy consumption and use of centrifugal pumps for these processes will be low to keep shear forces at a minimum. 


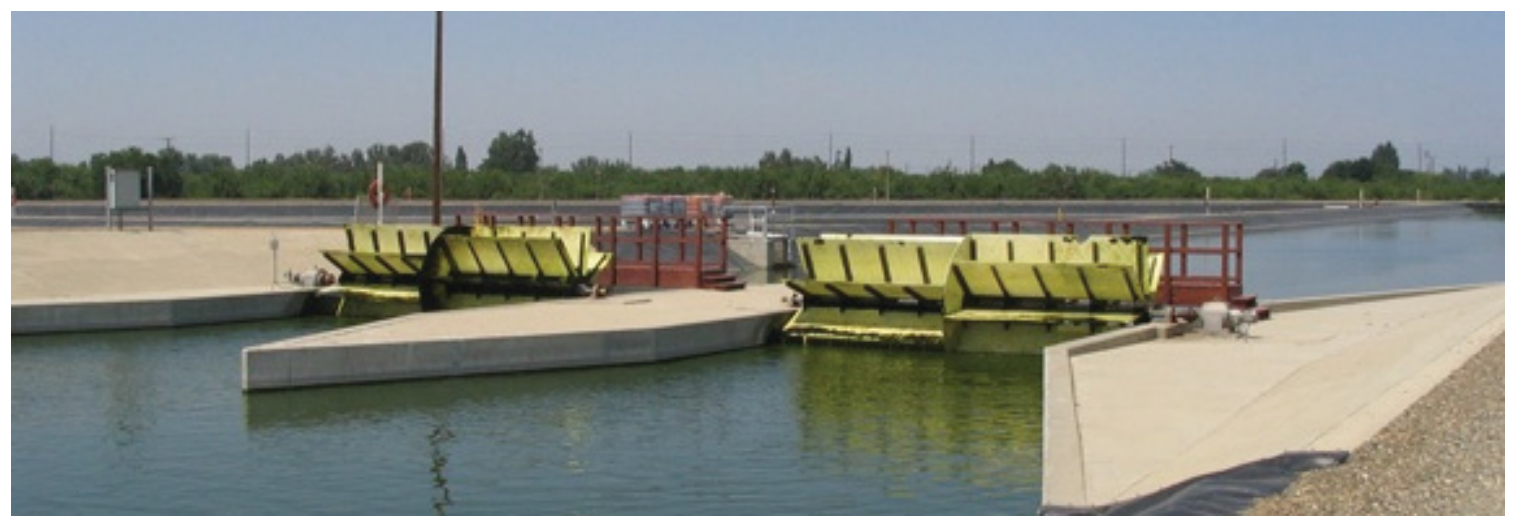

Figure 8. Example of a raceway paddle wheel system

(http://www.oilgae.com/club/users/tomcatino/blogs/1197).

\subsubsection{Carbonation systems}

The need for carbonation systems for algae raceway ponds is important due to the requirement of carbon for aggressive cultivation of algae. Each pond is equipped with a carbonation sump to supply the algae with $\mathrm{CO}_{2}$. During peak operation during the summer months, the need for equivalent carbon is greater due to greater productivities. The designs of the pond $\mathrm{CO}_{2}$ delivery systems are similar to those reported in Lundquist et al. (2010). Ponds have sump stations the length of the channel where $\mathrm{CO}_{2}$ is supplied to the culture. This $\mathrm{CO}_{2}$ is supplied by effluents from localized power plants, digesters, and combustion processes. Carbonation sump stations are located in each channel of the raceway and are equipped with aeration units (sparger) that produce micro bubbles for $\mathrm{CO}_{2}$ distribution. The units are located roughly $1-\mathrm{m}$ deep and have a concrete pad or inlaid cinder blocks to decrease the amount of erosion from the moving culture.

Organic carbon from wastewater is another form of carbon used for algae cultivation. Wastewater provides water and nutrients that has the potential to contain enough $\mathrm{CO}_{2}$ from wastewater BOD to supply the algae for several hours (Lundquist et al. 2010). Supplementary $\mathrm{CO}_{2}$ by means of exogenous effluents may be required to supply the remaining required $\mathrm{CO}_{2}$ for growth.

\subsubsection{Instrumentation for Cultivation}

Monitoring parameters can include $\mathrm{pH}$, culture temperature, $\mathrm{CO}_{2}$ saturation, salinity, light exposure, etc., which each pond will need for automated instrumentation to communicate to the central facility. Each pond will have an instrumentation unit with monitoring probes that send data to and from the central processing facility that operates and monitors culture characteristics (Figure 9). The central processing facility will be equipped with programming units that control water/wastewater flow into and out of the pond while also automatically monitoring and controlling nutrient delivery. The central facility and pond monitoring systems are permanent fixtures that are built into the farm and pond configurations.

Ideally, the plant manager and operations supervisor will monitor pond conditions and identify culture conditions where specific samples need to be collected for analysis. The laboratory manager and staff scientist will use these monitoring instrumentation units to track culture conditions and maturity (lipid content). As the conditions of the culture reach maturity, automated processes allow the plant manager initiate harvesting/dewatering steps remotely while monitoring efficiency. 


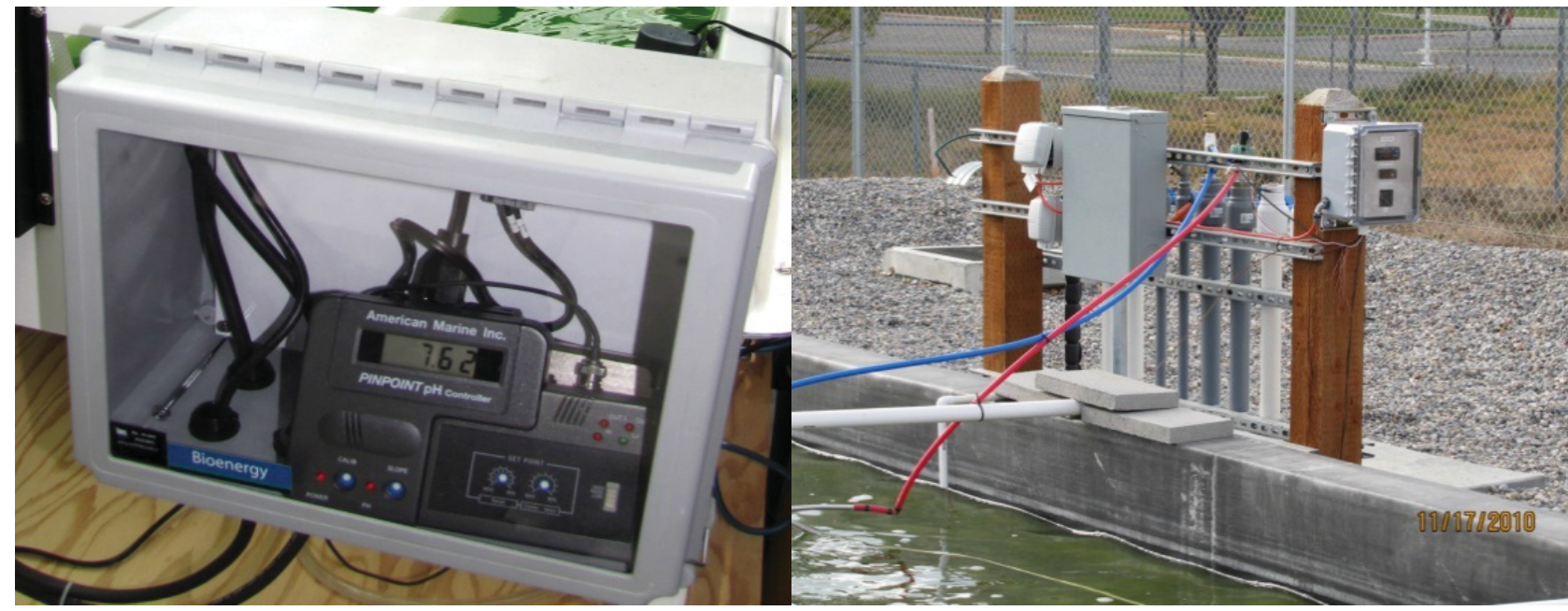

Figure 9. Temperature/pH monitoring systems for algae cultivation.

\subsubsection{Inoculum Systems}

The inoculation system is a step-up pond configuration that increases 10-fold at each stage for an adequate inoculum for the 10-acre (4-ha) raceways (Figure 10). This system is one scenario of many that would allow inoculation of the larger raceways. The inoculation concept starts with photo-bioreactors (PBR) growing 50 liters of culture. These PBRs would grow culture inoculums for basic raceways equipped for 500 liters of culture. At each stage of the step-up pond inoculums system, nutrients and water (10-fold scale-up) will be present and combine with the inoculums for continuous growth. The 500 -liter raceway inoculums would then feed a 5,000-liter $\left(5-\mathrm{m}^{3}\right)$ pond. This pond would then serve a much larger 50,000-liter $\left(50 \mathrm{~m}^{3}\right)$ pond, and so on. A $10 \%$ inoculum for a 4-ha $\left(12000-\mathrm{m}^{3}\right)$ pond is assumed to be $144,000,000\left(1200 \mathrm{~m}^{3}\right)$ liters. The fifth raceway in the sequence would have a rough total of 5,000,000 $\left(5,000 \mathrm{~m}^{3}\right)$ liters of algae, which theoretically contains enough starter culture to inoculate a little over (4) 4-ha cultivation ponds. Assuming (100) 4-ha ponds, (25) 5-inoculum step pond systems would need to be built.

Obviously, this is a large addition to the (10) $1000-\mathrm{m}^{2}\left(300-\mathrm{m}^{2}\right)$ ponds discussed in previous reports (Lundquist et al. 2010), but those reports do not describe in detail as to how their inoculums system would function (Benemann et al. 1982; Benemann and Oswald 1996; Davis et al. 2011; Lundquist et al. 2010).

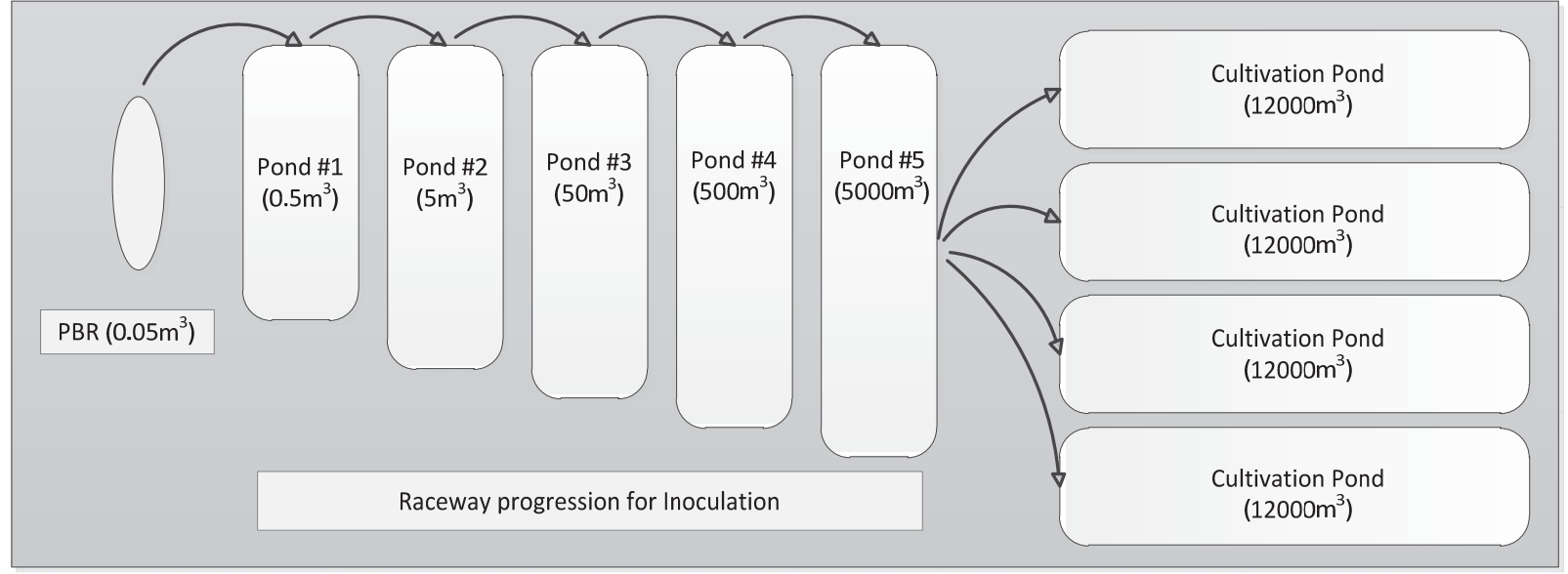

Figure 10. Inoculation pond configuration. 
The need for a 25-pond system would not be ideal for continuous harvest. The need for inoculation or re-inoculation is reserved for ponds that are starting, contaminated, or overcrowded with waste and need to be cleaned. A more reasonable number might be closer to 2-5 systems. The PBRs have not been included in this scenario because of the small scale of these units compared to the larger raceways. Also, several smaller units might be needed to start the 50-L initial starter cultures. The inoculum PBR reactors at the small scale are very basic plastic tube reactors with nutrients, water, and $\mathrm{CO}_{2}$. The inoculum raceways at each scale will be lined ponds similar to the larger ponds, outdoor, paddle-wheel mixed with greenhouse like covers over the initial 1-2 raceways. These covers will help maintain culture integrity and allow the culture to grow adequately dense for transfer to the next stage. Although this step-up pond configuration system has been described here, more experiments need to be performed to confirm the viability of the $10 \%$ inoculums for each raceway.

\subsection{Harvest and Dewatering}

Harvesting and dewatering is a necessary step for concentrating the microalgae for further processing and conversion downstream. The process is challenging due to energy inputs, stability concerns, and final product constraints that may limit the methods for concentrating the microalgae. This process must maintain lipid stability or secondary product stability for adequate process viability. To efficiently dewater biomass, significant advances must be made to decrease costs associated with removing water. Concurrent dewatering techniques have been proposed to sufficiently dewater cultures for direct wet extraction of lipids or transport through a drying step (Clarens et al. 2010; Davis et al. 2011; Lundquist et al. 2010; Molina Grima et al. 2003)

Major harvesting and dewatering techniques for algae include flocculation, sedimentation, dissolved air flotation, filtration, electroflocculation, and centrifugation (Figure 11).

- Flocculation additives have included a variety of polymers, salts, surfactants, alum, lime, and cellulose (DOE 2010).

Flocculation allows greater cell aggregation and densification with minimal energy expenditure (Elmaleh 1991; Venkataraman 1978).

- Sedimentation and dissolved air flotation allow similar results with sometimes longer retention times (Knuckey et al. 2006).

- Substantial dehydration processes such as filtration and centrifugation can be effective but constitute large portions of the processing costs and can influence the economics (70-75\% processing costs) of harvesting (Mohn 1978).

- Electroflocculation has been used in the treatment of polluted water and is now being investigated for the harvesting and extraction of algae and its constituents.
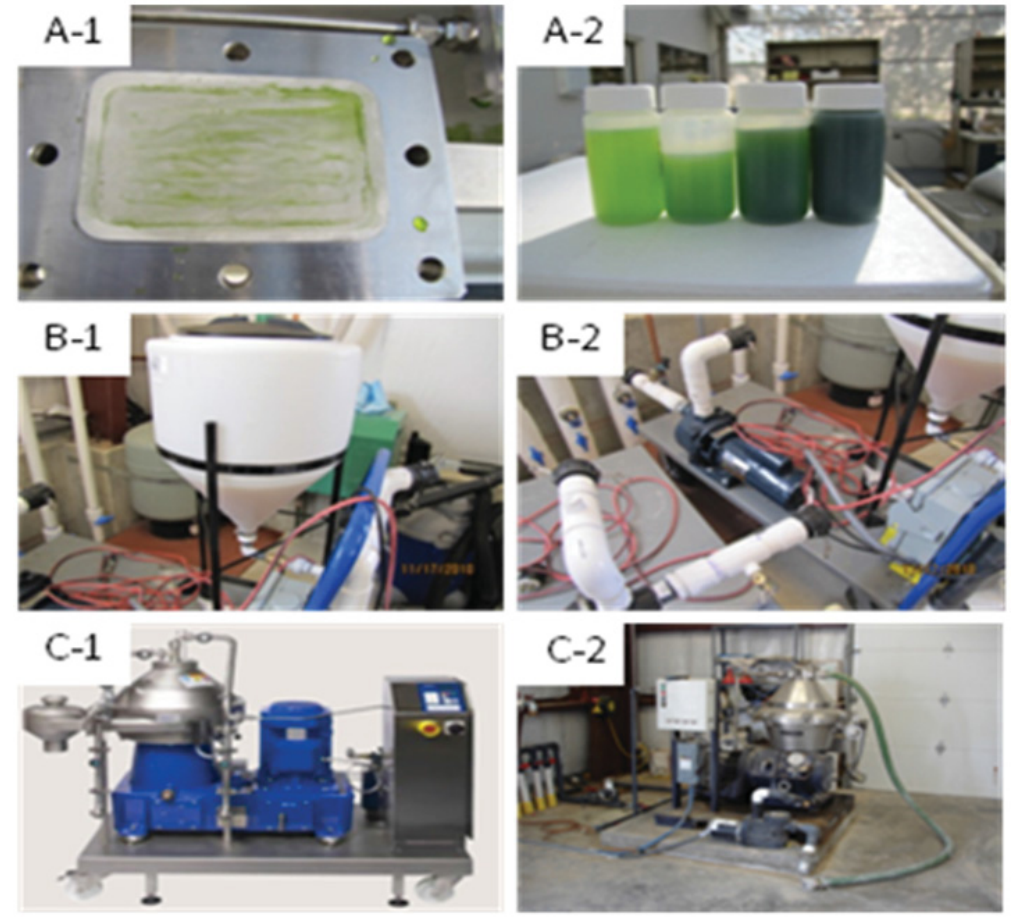

Figure 11. Dewatering techniques, filtration (A-1,2), flocculation (B-1,2), and centrifugation $(\mathrm{C}-1,2)$. 
Proposed algae harvesting designs incorporate primary and secondary harvesting stations and steps within the dewatering process. These processes initially replicate wastewater treatment plants with sedimentation tanks as primary harvesting stations. Primary harvesting stations are composed of large containers (whether plastic or earthworks) that hold the algae culture for a predetermined time and allow the culture to naturally auto or bioflocculate (Benemann and Oswald 1996; Molina Grima et al. 2003). Sedimentation alone or in conjunction with chemical flocculation occurs in secondary containers to concentrate the culture in preparation for further dewatering. Centrifugation is often the secondary harvesting technique (Benemann and Oswald 1996). Primary harvesting steps of sedimentation and flocculation before centrifugation remove enough water to lower the cost of centrifugation. Although there have been a variety of designs presented for harvesting algae from a liquid culture, not a single scenario has been outlined as ideal (Benemann and Oswald 1996; Davis et al. 2011; Lundquist et al. 2010; Sheehan et al. 1998).

The harvesting elements often used in large-scale production first include natural settling of the culture followed by a primary harvesting step using flocculation while secondary harvesting uses a centrifuge (Harmonization paper). In addition to the configurations discussed above, additional equipment from industry are making strides in dewatering that can provide a continuous-flow harvesting system that is capable of harvesting directly from the cultivation system to dewater a culture to $95 \%$ solids (Industrial Partner-Personal Communication). This employs a chemical-free, low-energy flocculation alternative to current design configurations.

\subsubsection{Natural Settling and Flocculation}

Flocculation of algae is a process to increase the density of the culture by aggregating the microalgae cells by natural, chemical or physical means (Figure 12). Through flocculation, algae cells will aggregate in solution and allow for more effective cell recovery through sedimentation and centrifugation (Elmaleh 1991). Algae naturally have a negative charge on their surface which keeps them dispersed in suspension.

In most cases like autoflocculation and chemical flocculation, the surface charge is neutralized by the floc, which causes aggregation of the cells (Becker 1994; Molina Grima et al. 2003). In some cases however, old or fasting culture cells will produce products that aid in neutralizing this negative charge and causes the cells to settle. In some cases such as Nanochloropsis and

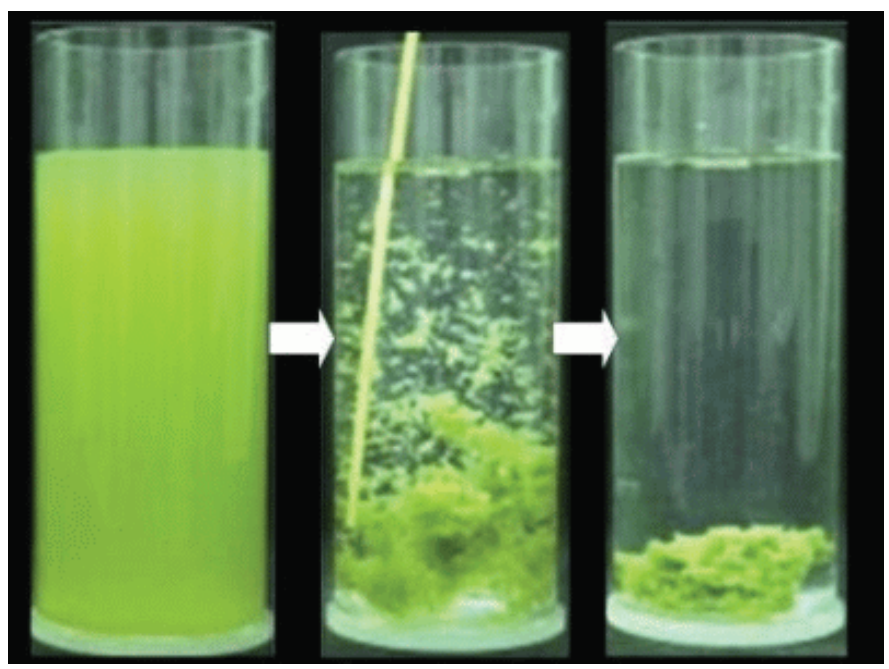

Figure 12. Example of algae flocculation

(http://www.bpe.wur.n1/UK/Research/Projects/Biofuels+ from + microalgae. + Harvesting + of + algae + for + oil + extraction/). Synechocystis, however, cultures have challenges with autoflocculating and additional technologies are needed to increase these cell densities during harvesting (Industrial Partner-Personal Communication).

Depending on the downstream uses for algae after lipid extraction, the secondary uses of algae should not be affected by chemical flocculants. The flocculants should be inexpensive, easily produced, and used at low concentration while still being effective. Chemical flocculants can include metal salts and cationic polymers(Benemann 1980; Golueke 1965; McGarry 1970). Autoflocculation techniques like changes in $\mathrm{pH}$ of the broth have been effective but can lyse cells and cause an early release of lipids(Blanchemain 
and Grizeau 1999). Co-cultures with bacteria that naturally release a flocculent type product have been identified as effective bioflocculents (Oh et al. 2001).

\subsubsection{Centrifugation}

Centrifugation has been used to harvest algae for experimental and commercial purposes (Burlew 1953; Golueke 1965; Mohn 1978). Centrifugal efficiency and throughput depends on the characteristics of the feed. Characteristics such as particle density differences, $\%$ solids, and particle size can affect the performance. Minimizing throughput volume has the potential to decreases costs associated with centrifugal dewatering. In general, centrifugation is an energy intensive process and has been suggested as a secondary dewatering process to reduce costs (Figure 13). Centrifuge systems can include bowl separators, intermediate and continuous dischargers, and screw conveyers. Continuous discharge centrifuges that allow solids and decant water discharge have been shown to be most effective (Benemann and Oswald 1996; Mohn 1978; Mohn 1980).

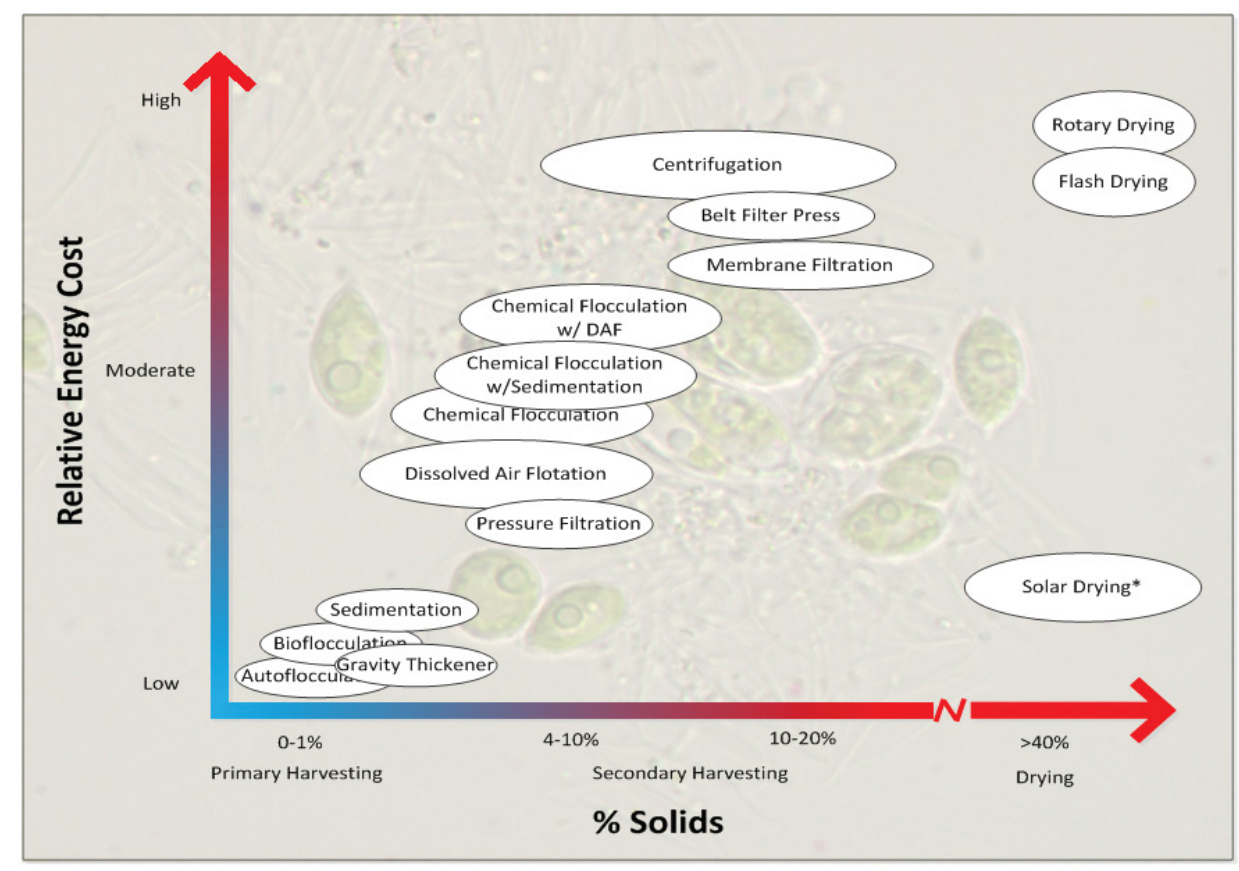

Figure 13. Qualitative costs associated with \% solids harvesting potential.

As stated previously, centrifugal efficiency and throughput depends on the characteristics of the feed. Particle density differences, \% solids, and particle size can affect efficiency of centrifugation. Minimizing throughput volume has the potential to decreases costs associated with centrifugal secondary harvesting (Table 5). Centrifuge systems can include bowl separators, intermediate and continuous dischargers, and screw conveyers. Continuous discharge centrifuges that allow solids and decant water discharge have been shown to be most effective (Benemann and Oswald 1996; Mohn 1978; Mohn 1980). 
Table 5. Harvest techniques and \% solid content output.

\begin{tabular}{|l|c|c|}
\hline \multicolumn{1}{|c|}{ Harvesting Process } & $\begin{array}{c}\text { Algae Solids Content in Feed } \\
(\% \text { solids })\end{array}$ & $\begin{array}{c}\text { Qualitative Energy Requirement } \\
\text { (low, medium, high) }\end{array}$ \\
\hline Initial Sedimentation & $0.01-1.0 \%$ & Low \\
\hline Autoflocculation & $1.5-2.0 \%$ & Low \\
\hline Bioflocculation & $1.5-2.0 \%$ & Low \\
\hline Chemical Flocculation & $\sim 5 \%$ & Moderate \\
\hline Dissolved air flotation & $\sim 4.0-6.0 \%$ & High \\
\hline Chem Floc /w DAF & $\sim 5-7 \%$ & High \\
\hline Chem Floc / w Sedimentation & $\sim 5-10 \%$ & High \\
\hline Filtration & $2-6 \%$ & High \\
\hline Belt filtration & $0.5-5 \%$ & High \\
\hline Centrifugation & $10-20 \%$ & Low \\
\hline Microstraining & $3-8 \%$ & \\
\hline
\end{tabular}

The Alfa Laval centrifuge has a throughput of $8,000 \mathrm{~m}^{3} \mathrm{~h}^{-1}$ and uses $10.1 \mathrm{~kW} \mathrm{~h}^{-1}$. This centrifuge has a maximum throughput capacity of $9,000 \mathrm{l} / \mathrm{h}$ with a bowl speed of $8,400 \mathrm{rpms}$. The $20 \%$ solids discharge from centrifugation will be fed onto solar drying beds or transported to an extraction facility. Water will be returned to the production ponds for replenishment and recycle of water and excess nutrients still available in the decanted water.

\subsubsection{Lipid stability during harvest and dewatering}

A question that arises when considering the logistics of moving harvested algae to a central processing plant is whether the lipid content remains stable or how long the lipids remain stable. It is possible that microalgae or associated bacteria could consume components of the algae, including the stored triglyceride. Lipid stability in biomass during production, extraction, and storage is important for maintaining the integrity of lipids and fatty acids for future conversion to fuels. Lipid breakdown is evident by the rancidity of the oil and breakdown products (Kim et al. 2007), and oxidation results in an aldehyde smell with other compound aromas. The breakdown of lipids can occur through many pathways, two of which can include autoxidation and photo-oxidation.

The oxidative stability of biodiesel fuels poses a serious challenge to industry, and its stability is largely governed by the degree of saturation of fatty acid chains. Polyunsaturated acyl chains are readily susceptible to oxidation, leading to deterioration of the fuel. Autoxidation of unsaturated fatty acids gives rise to the reduced oxidative stability of biodiesel produced from algal feedstocks. $\mathrm{Th}_{\mathrm{CH}} \mathrm{CH}_{2}$ positions that are allylic $\left(\mathrm{H}_{2} \mathrm{C}=\mathrm{CH}-\mathrm{CH}_{2} \mathrm{R}\right.$, where $\mathrm{R}$ is the connection to the rest of the molecule) to double bonds are the most prone to oxidation in the fatty acid chains. Fatty acids such as linoleic and linolenic have doubly allylic positions which make them extremely susceptible to autoxidation. Oxidation of fatty acid chains is enhanced by the presence of air, light, high temperatures, trace metals, peroxides, and the presence of double bonds in unsaturated fatty acids (Bajpai and Tyagi 2006).

Autoxidation is mediated by a free radical reacting with an organic substrate that yields hydroperoxide or oxygenated compounds (Frankel 1980). Photo-oxidative stressors in algae can cause an accumulation of reactive oxidative species which could damage cell membranes, macromolecules, and inhibit photosynthesis. In soy oil, a study comparing the thermal oxidation at $180^{\circ} \mathrm{C}$ and methylene blue photosensitizer of TAG showed that photosensitized TAG's decreased significantly when compared to thermally oxidized TAGs (Park et al. 2011). This would suggest that the oxidative stability of TAGs in photosensitized oxidation were lower when compared to thermal oxidation. This could be due to singlet 
oxygen oxidation which reacts with the unsaturated fatty acids. Singlet oxygen differs from free radical autoxidation by inserting oxygen at each end of the double bond, yielding an allylic hydroperoxide. Singlet oxygen are usually produced by photosensitizers like the photon capturing chlorophyll and chlorophyll-like sensitizers (Frankel 1980).

It is also thought that during the algal stress response to photo-oxidation, the excess electrons are taken up by the TAG synthesis pathway, thus serving a role in stress relief and TAG synthesis. During periods of light or nutrient stress, cells could use the overabundance of electrons for fatty acid synthesis and direct this action to TAG production. This could be one explanation of the increase in the amount of TAG produced during the stressor conditions (DOE 2010). Oxidation occurs more rapidly with polyunsaturated fatty acids than with monosaturated and saturated fatty acids, which facilitates an increase in the level of saturation of the remaining fatty acids. In some general sense, the percentage of monosaturated and saturated fatty acids increase when compared to polysaturated fatty acids during oxidation. Hydroperoxide, an initial product of lipid oxidation degrades causing volatiles like aldehydes and alcohols that cause rancidity (Kim et al. 2007; Min and Boff 2002). Oxidation of lipids can occur when exposed to light, air, transition metals, and elevated temperatures (Harris 2007; Mora-Gutierrez et al. 2010). A study on the stability of biodiesel from sunflower oil demonstrated that increases were measured in acid and peroxide content for storage temperatures of $50^{\circ} \mathrm{C}$ and in the presence of light (Du Pleiss et al. 1985). Temperature and metallic storage containers have been shown to have a significant impact on the stability of biodiesel in storage (Bondioli et al. 1995). Antioxidants such as $\beta$-carotene and other carotenoids have the ability to help quench singlet oxygen and aid against lipid oxidation (Foote et al. 1970; Foote and Denny 1968; Kiritsakis and Dugan 1985). Naturally occurring carotenoids in algae help aid photon capture for photosynthesis and also can act as a barrier for photo damage. The maintenance of oxidative stability by introduction of caseins, for example used in combination with antioxidants like carotenoids are currently being researched (Mora-Gutierrez et al. 2010).

\subsubsection{Drying, On-site Storage, and Transportation}

Drying is the final processing step that may be necessary to ensure stable storage of algal biomass if the material does not go through extraction following harvesting. Dehydration is required for stabilization of the algal slurry, typically 5-15\% dry weight, after harvest (Molina-Grima et al. 2004). High-moisture algal slurries ( $90 \%$ moisture content) must be processed quickly, as spoilage can occur in a matter of hours in warm, humid climates. Dehydration of the algal biomass confers material stability, enabling long-term storage and transportation of the final product. However, the removal of moisture poses a significant challenge to economical production of algal biofuels and may account for $70-75 \%$ of the processing cost (Mohn 1978). This represents a major economic challenge for the production of low-cost commodities (fuels and animal feed) and high-value products (polysaccharides and $\beta$-carotene) (Molina-Grima et al. 2004). The energy requirements for drying are significant; regardless of which drying technology is selected, evaporating $1 \mathrm{~kg}$ of water will always require an energy input of more than $800 \mathrm{kcal}$ (Bruton et al. 2009; Shelef et al. 1984). In addition, drying methods vary widely in the extent of capital investment and in the energy required for operation. The selection of drying method is dependent upon the scale of operation and end-product use.

\subsubsection{Drying}

Drying methods are highly specific, and method selection must be tailored to the end-product use (Table 6). Methods that have most commonly been employed for drying microalgae include spray-drying, drum-drying, freeze-drying, and sun-drying. Given the high water content of algal biomass, sun-drying becomes problematic, and spray-drying is often too expensive for low-value commodities. Dehydration represents a significant cost to processing algal biomass, and when added to the cost of growth and harvesting, it poses a major economic barrier to the large-scale production of algal-derived bioproducts (Molina-Grima et al. 2004). 
Table 6. Summary of drying methods available with their advantages and disadvantages as well as possible co-products and drying efficiency of algal biomass.

\begin{tabular}{|c|c|c|c|c|}
\hline Method & Advantages & Disadvantages & Co-products & Efficiency \\
\hline Sun (solar) drying & $\begin{array}{l}\text { - No additional } \\
\text { energy inputs } \\
\text { - Low equipment } \\
\text { costs }\end{array}$ & $\begin{array}{l}\text { - } \begin{array}{l}\text { Degradation of } \\
\text { oil }\end{array} \\
\text { - Odor } \\
\text { development } \\
\text { - Contamination }\end{array}$ & - Animal feed & $\begin{array}{l}\text { - } 80-90 \% \text { solids } \\
\text { in } 1 \text { day }\end{array}$ \\
\hline Spray drying & $\begin{array}{l}\text { - Rapid, stable, } \\
\text { powder product } \\
\text { - Continuous } \\
\text { operation }\end{array}$ & $\begin{array}{l}\text { - High capital } \\
\text { costs } \\
\text { - High energy } \\
\text { input } \\
\text { - Deterioration of } \\
\text { algal pigments }\end{array}$ & $\begin{array}{l}\text { High-value } \\
\text { products such as } \\
\text { nutraceuticals }\end{array}$ & $\begin{array}{l}\text { - Dry product in } \\
\text { seconds }\end{array}$ \\
\hline Freeze-drying & $\begin{array}{l}\text { - Gentle method, } \\
\text { stable product }\end{array}$ & $\begin{array}{l}\text { - High capital } \\
\text { costs } \\
\text { - High energy } \\
\text { input } \\
\text { - Batch process } \\
\end{array}$ & $\begin{array}{l}\text { - High-value } \\
\text { products }\end{array}$ & \\
\hline $\begin{array}{l}\text { Rotary/Drum } \\
\text { dryers }\end{array}$ & & $\begin{array}{l}\text { - Additional } \\
\text { energy costs } \\
\text { - } \begin{array}{l}\text { Long periods of } \\
\text { elevated } \\
\text { temperature }\end{array} \\
\text { - } \begin{array}{l}\text { Flake not } \\
\text { powder }\end{array} \\
\end{array}$ & & $\begin{array}{l}\text { - } 90 \% \text { solids in } \\
1 \text { day }\end{array}$ \\
\hline $\begin{array}{l}\text { Macro- or } \\
\text { micro-electromag } \\
\text { netic waves }\end{array}$ & $\begin{array}{l}\text { - Targets only the } \\
\text { water } \\
\text { - Uniform heating } \\
\text { - Lower } \\
\text { equipment cost }\end{array}$ & $\begin{array}{l}\text { - Some capital } \\
\text { and energy costs }\end{array}$ & & \\
\hline $\begin{array}{l}\text { Flash (Pulse) } \\
\text { drying }\end{array}$ & $\begin{array}{l}\text { - } \begin{array}{l}\text { Rapid, fine } \\
\text { powder stable } \\
\text { product }\end{array} \\
\text { - Low } \\
\text { degradation } \\
\text { - Short residence } \\
\text { time }\end{array}$ & $\begin{array}{l}\text { High initial } \\
\text { moisture content }\end{array}$ & $\begin{array}{l}\text { - High value, high } \\
\text { purity products }\end{array}$ & $\begin{array}{l}\text { - } 99 \% \text { solids } \\
\text { content can be } \\
\text { achieved }\end{array}$ \\
\hline
\end{tabular}

Solar Drying. Solar drying is one of the oldest methods for food preservation and is still in use today. Traditional sun drying is accomplished by exposing the product to direct sunlight by laying it on mats, roofs, or drying floors. Sun drying may be the only economically viable option for drying algal biomass without additional fuel consumption. However, exposure to solar radiation causes oil and chlorophyll degradation in the algal biomass, and the temperature increases experienced during the process of drying can contribute to the deterioration and oxidation of algal fatty acids. Sun drying can be used to dry an algal slurry to $80 \%$ solids in one day (Lundquist et al. 2010) and may be an acceptable solution if the algal co-product is to be used for animal feed. A mixture of sun-dried Spirulina and corn meal can be 
dehydrated to $10 \%$ water within one day and has been used successfully as fish feed in Israel, serving as the sole diet for Tilapia fish (Shelef et al. 1984).

Flash Drying. Flash drying is well-suited for drying pasty products which are obtained from centrifuges, rotary filters, or filter press (Mujumdar, 2006). In flash drying, the wet cake gets fluidized under the action of hot air and mechanical dispersion; this hot air stream conveys the material through a drying duct. Drying can be accomplished rapidly and efficiently due to the high heat and mass transfer coefficients achieved through velocity and agitation. Feed material must be granular and free flowing when dispersed in the gas stream. The short residence time (seconds) of flash dryers necessitates a homogeneous feed material and rapid, even dispersion of the wet material into a drying airstream.

Spray Drying. For high-value products (more than $\$ 1000 /$ ton), spray-drying is the method of choice for retaining biomass in its entirety (Molina-Grima et al. 2004). However, spray-drying can cause deterioration to algal components, such as pigment. Spray-drying enables rapid, continuous, drying of slurries, solutions, or emulsions. Although spray-drying is widely used for stabilizing algal biomass, it is one of the most expensive methods available (Bruton et al. 2009). In spray-drying, a slurry solution is sprayed into a hot air stream in the form of a mist or fine droplets (Geankoplis 1993). Fine droplets are formed from the liquid by spray nozzles or centrifugal atomizers. When atomized droplets are brought into contact with hot air, water is rapidly vaporized from the droplets. The small droplet size provides high surface area, which allows for such rapid rates of evaporation with drying times measured in seconds. Cyclonic air flow and drier dimensions prevent droplets from sticking to the walls. The dried product then settles to the bottom of the drier.

Spray-drying is advantageous in that it offers continuous operation, powdered product that requires no further size reduction, and rapid drying to ensure product quality (Molina-Grima et al. 2004). However, the sensitivity of algal biomass to oxidation may require the addition of antioxidants in some instances.

Freeze Drying. Freeze-drying (lyophilization) is a process whereby heat and mass transfer occur simultaneously. The algal slurry to be dehydrated is frozen, and the ice is sublimed by slight warming without thawing. Ice is sublimed to vapor by reducing the pressure below the triple point of water (partial vapor pressure of $4.6 \mathrm{mmHg}$ ). Lyophilized dry material contains multiple interstices into which water can penetrate, allowing for rapid re-hydration (Molina-Grima et al. 2004). Since the material is frozen, constituents of the algal biomass remain fixed during the process of sublimation drying. The temperature at which the dried material is kept in storage is critical to determining the product stability during storage (Snowman 1996). Freeze drying is advantageous because it is the gentlest method for drying algal biomass. However, the high capital costs and high energy costs of freeze drying reserve its use for applications where the biochemical character of the material must be retained (Molina-Grima et al. 1996). Commercial-scale lyophilization is only considered for high-value products.

Drum Drying. Rotary dryers are sloped, rotating cylinders that use gravity to material from one end to the other. Wet solids are fed at the high end of the dryer and move through the cylinder as it rotates. Heating may occur by direct contact with hot gases, or indirect contact through the heated cylinder walls (Geankoplis 1993). A rotary-drum dryer consists of a heated metal roll to which a thin layer of liquid slurry is applied and evaporated to dry solids. The dry solids are then scraped off of the rotating drum. Rotary drum dryers have been extensively used in heat drying of wastewater sludge (Shelef et al. 1984) and is also a common method for algal drying. In an assessment of the feasibility of the commercialization of algal culture in Alabama, drum drying was the method selected for algal drying (Putt 2007). In this design, a belt filter press is used to dewater algae (from 3-20\% solids) prior to drum drying; the dried algal product would then be removed from the drums in a paper-like structure that can be wound in rolls for storage and transportation. A methane-fired forced air heater (powered by the anaerobic digestion of animal litter) provides the heat for the drum dryer in this scenario. In the design by Putt (2007), anaerobic digesters are capable of producing $26 \mathrm{~kW} /$ acre (625 kWh/day) of thermal energy; 
this is more than adequate for drying the algae from $20 \%$ to $90 \%$ solids, which requires a latent heat of $170 \mathrm{kWh} /$ day/acre.

Solar drying at large scale. Solar drying is the only feasible method for large-scale drying of wet algal biomass without additional fuel consumption and associated costs. Significant area, as much as $100 \mathrm{~m}^{2} / \mathrm{m}^{3}$ of biomass, and infrastructure is required to for solar drying and has been modeled after Lundquist et al. (2010). A thin layer of algal biomass is spread over low-density polyethylene liners and dried to at least $80 \%$ solids, which is thought to be achievable in 24 hours. A modified scraper or vacuum truck is used to harvest the algae; concrete tracks may be required to protect the polyethylene liner (Lundquist et al. 2010). Given the large area required for biomass drying, advanced mechanization is required for recovery of the dried algal biomass. To ensure stability for on-site storage, Lundquist et al. (2010) assume that solar-dried biomass, $80-85 \%$ solids content, is further concentrated by a natural gas-fueled flash dryer to a final solids content of $90-95 \%$ prior to storage.

\subsubsection{Storage}

The stability of algal biomass under different storage and transport scenarios is relatively unknown. Previous work has shown that the presence of naturally occurring bacterial communities enhances the rate of algal degradation (Rieper-Kirchner 1990). Given the variety of potential culturing and harvesting conditions, i.e., $\mathrm{pH}$, salinity, level of dewatering, it is largely unknown how the combination of such factors will affect storage, transportation, and the subsequent quality of the fuel product (DOE 2010). Similar to plant lipids, factors like material and temperature should be considered for their influence on the stability of algal lipids during storage (Hu et al. 2008).

\subsubsection{Transportation}

The optimization of transport, both energetically and economically, relative to the location of production sites and biorefining facilities has been a challenging issue for lignocellulosic feedstocks (Hess et al. 2009) and poses a similar challenge to large-scale algal production systems. Transport of algal biomass from the unit farm to centralized extraction facilities should conform to existing standards in order to minimize infrastructure impacts.

Alteration of density and format through mechanical densification may be required to improve efficiencies in transportation and handling scenarios. However, the effect of densification on dried algal biomass prior to extraction of oil is unknown.

Some work has shown that co-pelletization of algal biomass with barley effectively pasteurizes the densified product, improving stability and digestibility for use in animal feed (Lundquist et al. 2010).

\subsection{Conversion Pathways for Algal Biofuel Production}

Multiple conversion strategies exist for deriving biofuels from algal feedstocks. In order to make microalgae cost-competitive for biofuels production, all algal fractions, not just lipids, must be utilized.

Most algal biofuels research has focused around biochemical conversion strategies for production of biodiesel. Oil recovery from algal cells is facilitated by an extraction step. Frequently, this is accomplished through a solvent extraction; however, other possibilities include mechanical extraction, supercritical $\mathrm{CO}_{2}$ fluid extraction, electroporation, ultrasonic methods, and 'algal milking' (Pienkos and Darzins 2009). Algal oil consists of triglycerides (TAGs), which represent an attractive feedstock for biodiesel. In transesterification, TAGs are treated chemically or enzymatically (e.g., lipases) to produce glycerol and fatty acid methyl esters (FAME) that are biodiesel (Chisti 2007). Catalytic upgrading of FAME can be used to produce diesel, kerosene and gasoline. After oil extraction, residual algal bodies can be enzymatically digested to release sugars for microbial fermentation to alcohols. 
Recent studies at Arizona State University (ASU) and National Renewable Energy Laboratory (NREL) have shown promise for coupling dilute-acid pretreatment of microalgae with biochemical conversion (Pienkos 2013). Dilute-acid pretreatment resulted in successful fractionation of algal carbohydrates and lipids with high recovery. Robust fermentation of carbohydrate fractions was achieved with maximum utilization in 6-36 hours by two different fermentation organisms (Saccharomyces cerevisiae D5A or Zymomonas sp.). This demonstrated, whole-cell processing approach offers advantages for algal biofuel and co-product production. In order for large-scale production of algal biofuels to be economically viable, whole-cell processes that exploit all algal fractions must be realized.

Torrefaction, pyrolysis, gasification, and hydrothermal liquefaction are potential thermochemical conversion schemes for microalgal biofuels production. In torrefaction, dry biomass is typically processed anoxically at $200-300^{\circ} \mathrm{C}$ and atmospheric pressure. Torrefaction produces a low-value, solid char from the partial decomposition of biomass, which has discouraged research and application of this technology for algal biofuels production (López Barreiro et al. 2013).

Pyrolysis is a thermal treatment of biomass performed under anoxic conditions at temperatures of $400-600^{\circ} \mathrm{C}$ and atmospheric pressure, converting dry biomass to 'bio-oil', charcoal, and gas. Fast pyrolysis is a technique that uses very high heating rates $\left(1000^{\circ} \mathrm{C} \mathrm{min}^{-1}\right)$ and short residence times (seconds) to produce liquid fuel directly (López Barreiro et al. 2013). Fast pyrolysis tested with Chlorella protothecoides and Microcystis aeruginosa $\left(500^{\circ} \mathrm{C}\right.$ and heating rate of $\left.600^{\circ} \mathrm{C} \mathrm{min}^{-1}\right)$ resulted in unexceptional bio-oil yields of $18 \%$ and $24 \%$, respectively (Miao et al. 2004). Pyrolysis offers the advantage of whole-cell processing; however, the high energy costs associated with pyrolysis may limit its applicability and development for algal fuel production.

Gasification is the partial oxidation of biomass at high temperatures $\left(>700^{\circ} \mathrm{C}\right)$ and atmospheric pressure, producing syngas (producer gas). Syngas may be composed of $\mathrm{CO}, \mathrm{H}_{2}, \mathrm{CO}_{2}$, and $\mathrm{CH}_{4}$; it can be burned directly in gas engines or used to produce methanol $\left(\mathrm{CH}_{3} \mathrm{OH}\right)$ and $\mathrm{H}_{2}$. Syngas can also be converted to synthetic fuel via the Fischer-Tropsch process. Gasification of a microalgal paste consisting of $21 \%$ Spirulina at $850-1000^{\circ} \mathrm{C}$ produced syngas that was predominantly $\mathrm{H}_{2}, \mathrm{CO}_{2}$, and $\mathrm{CH}_{4}$ and resulted in a maximum theoretical methanol yield of $64 \%$ at $1000^{\circ} \mathrm{C}$ (Hirano et al. 1998).

A major limitation of thermochemical conversion technologies like torrefaction, pyrolysis, and gasification is that they require an input of relatively dry feedstock. Moisture content has a considerable impact on process conditions in thermochemical conversion; similarly, the quality and quantity of biofuel produced is dependent up the process conditions used in thermochemical conversion (López Barreiro et al. 2013). Most research on algal-derived biofuels has focused on biochemical conversion routes because processes that rely on dry algal feedstock are not considered economically viable due to the energy inputs associated with drying algal slurries or pastes (Chisti 2008). Thermochemical conversion technologies that are capable of handling wet algal feedstocks may be a viable, whole-cell processing alternative to biochemical conversion.

Hydrothermal gasification (or wet gasification) refers to a process where water in a supercritical state $\left(>374^{\circ} \mathrm{C}\right.$ and $\left.22.1 \mathrm{MPa}\right)$ acts as both a solvent and reactant. Typical process conditions are $360-700^{\circ} \mathrm{C}$ and 25-30 MPa (López Barreiro et al. 2013). Hydrothermal gasification has been examined for several strains of algae over a range of temperatures, reaction times, and algal loadings at relatively small scales(Chakinala et al. 2010; Guan et al. 2012a; Guan et al. 2012b; Haiduc et al. 2009; Stucki et al. 2009). Several advantages associated with this technology make it attractive for thermochemical conversion of microalgae: direct use of wet biomass, high efficiency, and potential for nutrient recycle to algal cultures. However, the high temperatures and harsh conditions required for hydrothermal gasification incur substantial energy and capital costs. In addition, the production costs exceed the value of the gas obtained.

Hydrothermal liquefaction (HTL) is a promising technology for the thermochemical conversion of wet microalgae to 'bio-oil,' a liquid energy carrier, which can be converted to hydrocarbons suitable as transportation fuels. HTL is considered both an extraction and conversion process; the hydrocarbon 
structure of algal lipids is almost completely retained, while a fraction of carbohydrate and protein is converted to oil. With HTL, oil yields are higher than with typical extractions (Fishman 2012). HTL is a medium-temperature, high-pressure conversion technique capable of processing whole algal biomass (or residual algal fractions following lipid extraction) to bio-oil, along with gaseous, aqueous, and solid by-products (López Barreiro et al. 2013). The $\mathrm{CO}_{2}$ stream generated as a by-product of HTL can be fed back to cultivation ponds. Further, solid residue by-products of HTL may be used as a feedstock for a subsequent gasification step for the production of other energy carriers with remaining ashes recycled as nutrients for cultivation. The high water content of microalgae makes them an attractive feedstock for HTL in subcritical water (i.e., superheated water, pressurized hot water at temperatures great than $100^{\circ} \mathrm{C}$ and less than $374^{\circ} \mathrm{C}$ ). A recent study has shown encouraging results for achieving a positive energy balance with HTL (Xu et al. 2011); however, combined mass, energy, and nutrient balances must be considered for a thorough assessment of the feasibility of microalgal feedstocks for HTL.

A variety of pathways and approaches exist for conversion of microalgae to biofuels and co-products. Detailed techno-economic and life cycle analyses are required to determine whether algal biofuels can be produced in a manner that is economical and sustainable at scales required to make a significant contribution to U.S. fuel demand (Pienkos and Darzins 2009).

\section{OPEN-POND PRODUCTION SYSTEM ASSESSMENT}

Numerous studies have been performed examining the feasibility of open-pond algal (ANL et al. 2012; Benemann et al. 1982a; Davis et al. 2011; Lundquist et al. 2010; Richardson et al. 2010; Sheehan et al. 1998; Sun et al. 2011; Wigmosta et al. 2011; Zamalloa et al. 2011). Sun et al. (2011) performed a comparative analysis of previous studies from U.S. Department of Energy national laboratories, industry and academia for producing TAG. Sun et al. was able to reduce the economic variability between the studies to $\$ 10.87$ to $\$ 13.32 /$ gal of TAG using a normalized set of input assumptions.

In 2011, the U.S. Department of Energy Bioenergy Technologies Office began an initiative to harmonize existing modeling effort across its national laboratories. The result was a conservative baseline open-pond algal production system used to assess several scenarios for obtaining the 5-BGY advanced fuel goal established in the Energy and Security Independence Act of 2007. The algal production system has a total footprint of 1,200 acres with 1,000 acres of open ponds. A three-stage harvest and dewatering process, consisting of sedimentation, chemical flocculation, and centrifugation, was used to increase the algae density to $200 \mathrm{~g} / \mathrm{L}$. Extraction was then performed on the algal slurry using a hexane solvent and centrifuge to separate the TAG from the algal biomass and solvent. The solvent is recovered and recycled and the algal biomass is sent to an anaerobic digester. The TAG is sent to a shared conversion facility toproduce biodiesel. The study performed economic assessments using steady-state and seasonal productivity assumptions. Algal production systems along the U.S. Gulf Coast were clustered and the average productivity was assessed. The cost of biodiesel between the clusters varied as much as $\$ 3.50 / \mathrm{gal}$ of biodiesel using the steady-state assumption. Implementing seasonal productivity increased the cost of biodiesel by nearly $\$ 1.00 /$ gal (ANL et al. 2012).

Idaho National Laboratory developed a method for assessing algal production systems considering high-fidelity spatial and temporal data. The approach addresses current limitations for assessing algal production systems including the ability to (1) quickly assess alternative algal production system designs, assess spatial and temporal variability using high-fidelity data, and (2) perform large-scale assessments considering multiple scenarios for thousands of potential sites. The approach uses a dynamic and modular methodology for determining the cost of producing TAG and biodiesel from open-pond systems (Abodeely et al. 2013). This approach is utilized to investigate several potential algal production sites in the Southeast and Southwest United States. 
Figure 14 shows the average cost per gallon of TAG and average annual TAG production using the harmonized baseline design. Daily productivity data is utilized to scale each process in the algal production system appropriately to handle material throughput during peak performance. The cost per gallon of TAG can vary from \$17.65-25.26 depending on location and resource requirements while production varied from approximately $0.9-1.3 \mathrm{MM}$ gallons of TAG. The relationship between the production capability of the site and the cost is evident. Although the downstream processes are scaled to handle the algae throughput throughout the year, the pond infrastructure requirements are common across the sites. The large discrepancies between the capital cost is generally attributed to the large investment required for the pond infrastructure. As a result, greater production potential helps lower the overall cost of producing TAG.

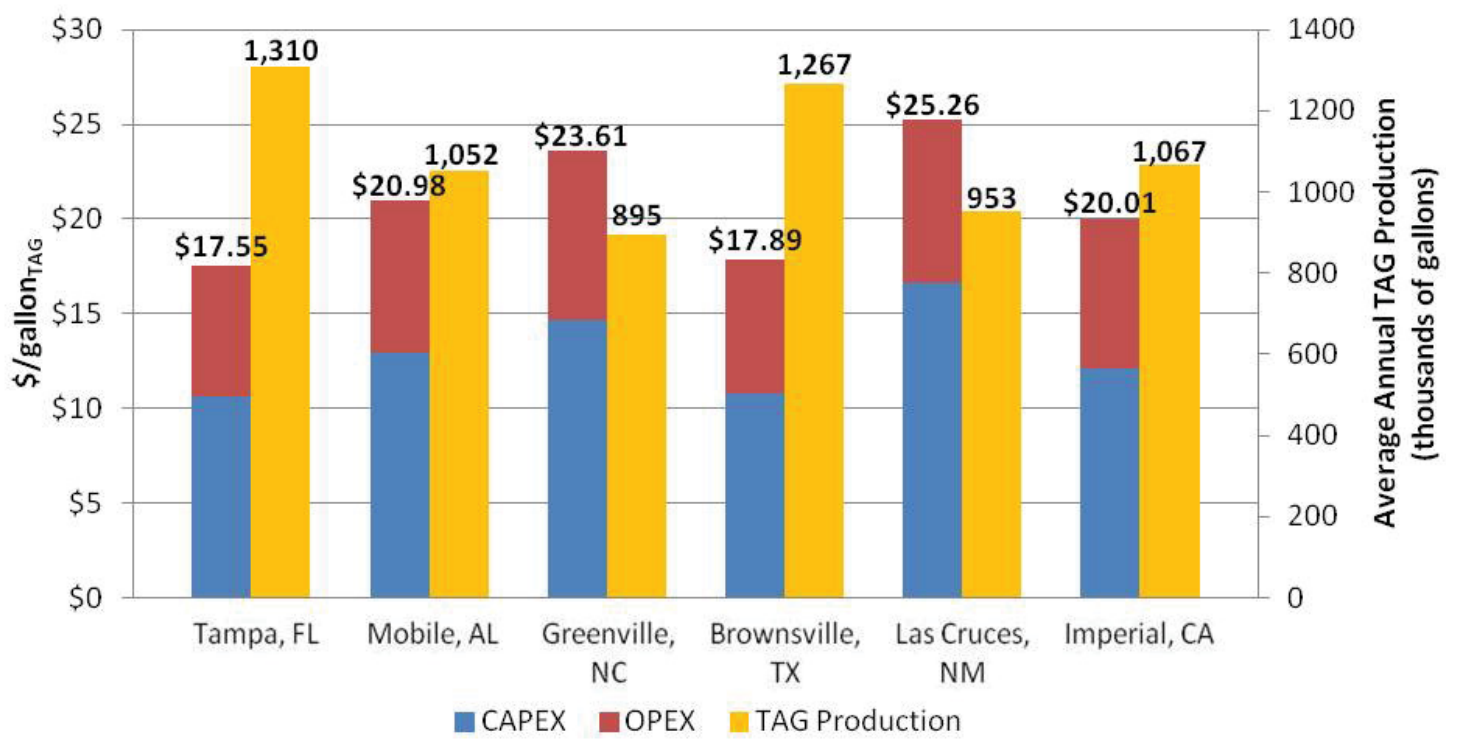

Figure 14. Cost assessment of the harmonized baseline design using high-fidelity productivity data with average annual TAG production.

The modular nature of the assessment tool enables processes to be interchanged or reconfigured. An alternative dewatering technology that uses electroflocculation is investigated in a couple alternative algal production system designs (Table 7). The first alternative design replaces the three-stage dewatering process. The first alternative design had higher capital costs relative to the baseline algal production system design but lower operating costs. This is due to the quantity of units of the alternative dewatering technology required to process the throughput for a 1,000-acre algal production system. Sedimentation offers a much lower cost option for the primary harvesting step. For this reason, the second alternative design uses sedimentation as the primary harvesting step, and the alternative dewatering technology is used to concentrate the microalgae from 1 to $20 \%$ solids. In this case, capital expenses were essentially the same, and operating expenses were lower compared to the baseline algal production system design (Figure 15).

Biological characteristics of microalgae play a significant role in making microalgae a viable feedstock for biofuel production. Figure 16 shows potential costs of TAG under theoretical biomass productivity and lipid content using the harmonized baseline algal production system design. Daily biomass productivity was increased and assessed by a factor of 0.5 , and lipid content was assessed at $5 \%$ increments. Results show that biological enhancements to microalgae alone are not sufficient to reduce the cost of using microalgae for biofuel production. Advancements in engineering to existing technologies or development of new, innovative technologies will also be needed. 
Table 7. Harmonized baseline design configuration with accompanying alternative design scenarios for the case study.

\begin{tabular}{|c|c|c|c|}
\hline Process & $\begin{array}{c}\text { Baseline/ } \\
\text { Harmonized Design }\end{array}$ & Alternative Design 1 & Alternative Design 2 \\
\hline Infrastructure & $\begin{array}{l}\text { Earthwork and installation } \\
\text { of open-pond } \\
\text { infrastructure }\end{array}$ & $\begin{array}{l}\text { Earthwork and installation } \\
\text { of open-pond } \\
\text { infrastructure }\end{array}$ & $\begin{array}{l}\text { Earthwork and installation } \\
\text { of open-pond } \\
\text { infrastructure }\end{array}$ \\
\hline Cultivation & Daily BAT productivity & Daily BAT productivity & Daily BAT productivity \\
\hline Dewatering & $\begin{array}{l}\text { Sedimentation - } \\
\text { Autoflocculation in } \\
\text { settling tank to } 1 \% \text { solids } \\
\text { (10g/L) } \\
\text { DAF - Chemical } \\
\text { flocculation with } \\
\text { collection by DAF; } 6 \% \\
\text { solids }(60 \mathrm{~g} / \mathrm{L}) \\
\text { Centrifugation - } \\
\text { Concentrate to } 20 \% \text { solids } \\
(200 \mathrm{~g} / \mathrm{L})\end{array}$ & $\begin{array}{l}\text { Alternative Dewatering } \\
\text { Technology - Concentrate } \\
\text { to } 20 \% \text { solids }(200 \mathrm{~g} / \mathrm{L})\end{array}$ & $\begin{array}{l}\text { Sedimentation - } \\
\text { Autoflocculation in } \\
\text { settling tank to } 1 \% \text { solids } \\
(10 \mathrm{~g} / \mathrm{L}) \\
\text { Alternative Dewatering } \\
\text { Technology-Concentrate } \\
\text { to } 20 \% \text { solids }(200 \mathrm{~g} / \mathrm{L})\end{array}$ \\
\hline Extraction & $\begin{array}{l}\text { High pressure } \\
\text { homogenizer } \\
\text { Liquid-liquid extractor }\end{array}$ & $\begin{array}{l}\text { High pressure } \\
\text { homogenizer } \\
\text { Liquid-liquid extractor }\end{array}$ & $\begin{array}{l}\text { High pressure } \\
\text { homogenizer } \\
\text { Liquid-liquid extractor }\end{array}$ \\
\hline $\begin{array}{l}\text { Anaerobic } \\
\text { digestion }\end{array}$ & $\begin{array}{l}\text { Methane production via } \\
\text { biomass/water; Digestate } \\
\text { sold for fertilizer, effluent } \\
\text { stream recycled }\end{array}$ & $\begin{array}{l}\text { Methane production via } \\
\text { biomass/water; Digestate } \\
\text { sold for fertilizer, effluent } \\
\text { stream recycled }\end{array}$ & $\begin{array}{l}\text { Methane production via } \\
\text { biomass/water; Digestate } \\
\text { sold for fertilizer, effluent } \\
\text { stream recycled }\end{array}$ \\
\hline
\end{tabular}

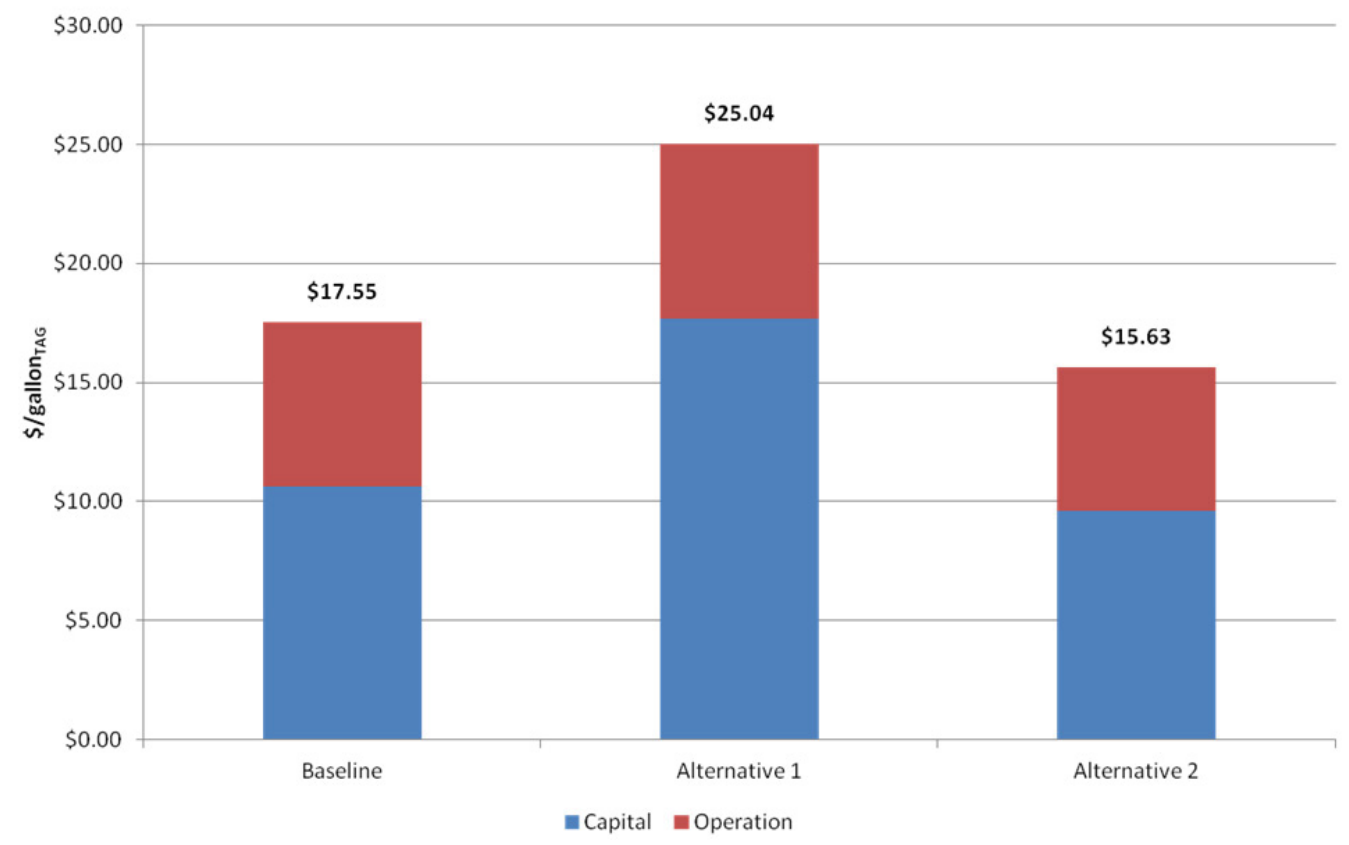

Figure 15. Cost comparison for alternative designs for the Tampa, FL site. 


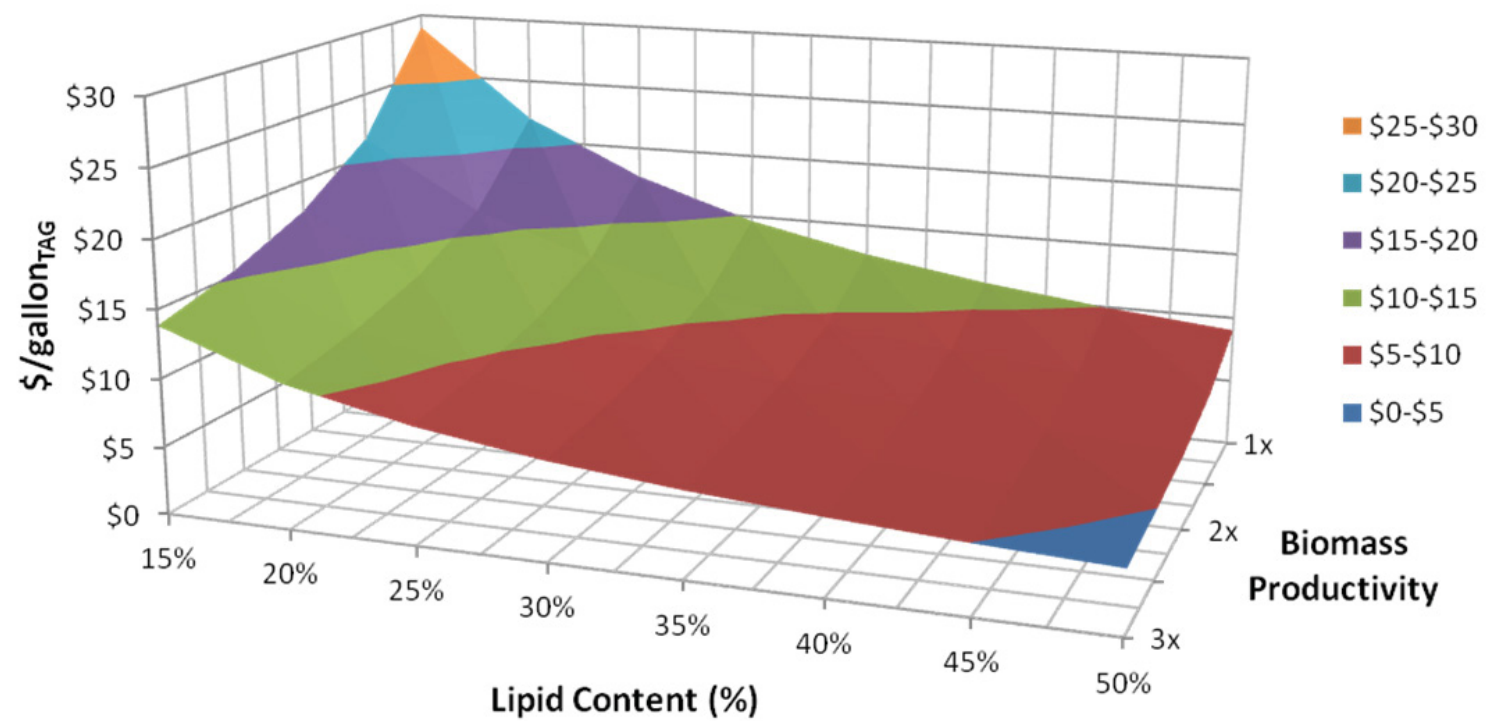

Figure 16. Assessment of algae characteristics.

\section{CONCLUSIONS}

The development of the algal biofuel and co-product industry has several obstacles that will need to be addressed for future systems to be economically viable. Microalgae characteristics such as productivity and lipid content will need to be improved through identification or engineering of algal strains that are best suited to specific locations. Challenges associated with developing technologies for inexpensive harvesting and dewatering will need to be overcome. The Baseline unit farm design assessment highlighted some of these barriers.

\subsection{Regional Assessment}

The Baseline unit Farm design was investigated across different regions of the United States to explore production capability and economic viability. As expected the southern United States appears to have the greatest potential for successful algal industries. The southwest United States provides ideal radiation and temperatures for microalgae production but is challenged with resource availability like water. The southeast has less ideal climate conditions (hurricanes, tornadoes, etc) but has greater access to resources. Most assessments of algal systems are representative of the southwest United States. This does not necessarily mean that locations further north should not be considered if an algal strain was identified or engineered for colder climates. Assessments of productivity in colder climates should be investigated to determine, if an ideal algal strain is found, if microalgae open-pond systems are feasible.

\subsection{Challenges and Future Work}

The challenges with viable algal systems are well documented. As discussed and analyzed, microalgae productivity and lipid content have the greatest potential for decreasing production cost given the current state of technology. As a result, research focused on developing highly productive, high lipid content algal strains is key for overcoming some of these challenges. Harvesting and dewatering are energy intensive processes that also will require advances to make the algal industry successful. This will require enhanced development of current technologies and development of new methods.

Other challenges related to resource availability will also need to be addressed. Most assessments assume co-location with wastewater treatment and industrial facilities to provide a majority of the water, 
nutrients, and $\mathrm{CO}_{2}$ needed for cultivating microalgae. While ideal, large-scale implementation of unit farms across the United States in most instances will not be able to be co-located with both or either type of facility. Investigation of nutrient and $\mathrm{CO}_{2}$ availability and delivery cost will need to be assessed on a per location basis. Water resources can also be an issue if a unit farm competes against current agricultural and social uses. In addition to water competition, locations requiring fresh water systems will need to consider the long-term impacts on underwater aquifers.

Future work will explore different approaches to these challenges and how to mitigate risk associated with large-scale, microalgae open-pond systems. Different production scenarios will be investigated across the United States for locations meeting the defined location criteria. Resource assessments for these locations will also be addressed to determine availability and economic viability of delivering the necessary resources where needed.

To develop the large-scale, open-pond microalgae systems, investors will require a highly productive, low risk facility. This will require an understanding of the potential annual variability at each location. Due to local climate and various weather patterns, productivity can suffer. Assessments using actual climate data instead of annual daily averages should be utilized to obtain more robust annual assessments of microalgae growth potential. This would enable more realistic assessments of production capability over the life of the unit farm. 


\section{REFERENCES}

Araujo, G. S., Matos, L., Goncalves, L. R. B., Fernandes, F. A. N., and Farias, W. R. L., 2011. Bioprospecting for oil producing microalgal strains: Evaluation of oil and biomass production for ten microalgal strains. Bioresource Technology 102, 5248-5250.

ANL, NREL, and PNNL, 2012. Renewable diesel from algal lipids: An integrated baseline for cost, emissions, and resource potential from a harmonized model, Argonne, IL: Argonne National Laboratory; Golden, CO: National Renewable Energy Laboratory; Richland, WA: Pacific Northwest National Laboratory.

Athenstaedt, K. and Daum, G., 2006. The life cylce of neutral lipids: Synthesis, storage and degradation. Cellular and Molecular Life Sciences 63, 1355-1369.

Bajpai, D. and Tyagi, V. K., 2006. Biodiesel: Source, Production, Composition, Properties and Its Benefits. Journal Of Oleo Science 55, 487-502.

Banerjee, A., Sharma, R., Chisti, Y., and Banerjee, U. C., 2002. Botryococcus braunii: A renewable source of hydrobarbons and other chemicals. Critical Reviews in Biotechnology 22, 245-279.

Becker, E. W., 1994. Microalgae: biotechnology and microbiology. Cambridge University Press, New York.

Ben-Amotz, A., Tornabene, T. G., and Thomas, W. H., 1985. Chemical profiles of selected species of microalgae with emphasis on lipids. J Phycol 21, 72-81.

Benemann, J., R., Koopman, B., Weissman, J., Eisenberg, D., Goebel, R., 1980. Development of microalgae harvesting and high rate pond technologies in California. In: Shelef G., Soeder C.J., editors. Algal biomass. Amsterdam: Elsevier, 457.

Benemann, J. R., Goebel, R. P., Weissman, J. C., and Augenstein, D. C., 1982. Microalgae as a source of liquid fuels. Final Techincal Report.

Benemann, J. R. and Oswald, W. J., 1996. Systems and Economic Analysis of Microalgae Ponds for Conversion of $\mathrm{CO}_{2}$ to Biomass.

Blanchemain, A. and Grizeau, D., 1999. Increased production of eicosapentaenoic acid by \&lt;i\&gt;Skeletonema costatum cells after decantation at low temperature. Biotechnology Techniques 13, 497-501.

Bondioli, P., Gasparoli, A., Lanzani, A., Fedeli, E., Veronese, S., and Sala, M., 1995. J. Am. Oil Chem. Soc. 72, 699-702.

Brock, T., Madigan, M., Martinko, J., and Parker, J., 1994. Biology of Microorganisms. Prentice-Hall, Inc., Englewood Cliffs, NJ.

Bruton, T., Lyons, H., Lerat, Y., Stanley, M., and Rasmussen, M. B., 2009. A review of the potential of marine algae as a source of biofuel in IrelandSustainable Energy Ireland, Dublin, Ireland.

Burlew, J. S., 1953. Algal Culture from Laboratory to Pilot Plant. Carnegie Institution of Washington Publication 600, Washington, D.C.

Chisti, Y., 1999. Shear sensitivity. In: Flickinger, M. C., Drew, S.W. (Ed.), Encyclopedia of Bioprocess Technology: Fermentation, Biocatalysis, and Bioseparation. Wiley, New York.

Chisti, Y., 2007. Biodiesel from microalgae. Biotechnology Advances 25, 294-306.

Chisti, Y., 2008. Response to Reijnders: Do biofuels from microalgae beat biofuels from terrestrial plants? Trends in Biotechnology 26, 351-352. 
Christie, W. W., 2003. Lipid analysis. The Oily Press, Bridgewater, NJ.

Clarens, A. F., Resurreccion, E. P., White, M. A., and Colosi, L. M., 2010. Environmental Life Cycle Comparison of Algae to Other Bioenergy Feedstocks. Environmental Science \& Technology 44, 1813-1819.

Davis, R., Aden, A., and Pienkos, P. T., 2011. Techno-economic analysis of autotrophic microalgae for fuel production. Applied Energy 88, 3524-3531.

DOE, 2010. National Algal Biofuels Technology Roadmap. U.S. Department of Energy, Office of Energy Efficiency and Renewable Energy, Biomass Program.

Du Pleiss, L. M., De Villiers, J. B. M., and Van Der Walt, W. H., 1985. Stability studies on methyl and ethyl fatty acid esters of sunflowerseed oil. J. Am. Oil Chem. Soc. 62, 748-752.

Ekman, A., Bulow, L., and Stymne, S., 2007. Elevated atmospheric $\mathrm{CO}_{2}$ concentration and diurnal cycle induce changes in lipid composition in Arabidopsis thaliana. New Phytol 174, 591-599.

Elmaleh, S., Coma, J., Grasmick, A., Bourgade, L., 1991. Magnesium induced algal flocculation in a fluidized bed. Water Sci Technol 23, 1695-702.

Foote, C. S., Chang, Y. C., and Denny, R. W., 1970. Chemistry of singlet oxygen. X. Carotenoid quenching parallels biological protection. Journal of the American Chemical Society 92, 5216-5218.

Foote, C. S. and Denny, R. W., 1968. Chemistry of singlet oxygen. VII. Quenching by.beta.-carotene. Journal of the American Chemical Society 90, 6233-6235.

Frankel, E. N., 1980. Lipid OxidationProgress in lipid research. Science and Education Administration, U.S. Department of Agriculture.

Geankoplis, C. J., 1993. Transport processes and unit operations. Prentice Hall, Inc., Englewood Cliff, NJ.

Golueke, C. G., Oswald, W.J., 1965. Harvesting and processing sewage grown planktonic algae. J Water Pollut Control Fed 37, 471-98.

Greenwell, H. C., Laurens, L. M. L., Shields, R. J., Lovitt, R. W., and Flynn, K. J., 2010. Placing microalgae on the biofuels priority list: a review of the technological challenges. Journal of The Royal Society Interface 7, 703-726.

Griffiths, M. and Harrison, S., 2009. Lipid productivity as a key characteristic for choosing algal species for biodiesel production. Journal of Applied Phycology 21, 493-507.

Harris, W. S., 2007. n-3 Fatty acid fortification: opportunities and obstacles. BJN 97, 593-595.

Hess, J., Kenney, K., Wright, C., Perlack, R., and Turhollow, A., 2009. Corn stover availability for biomass conversion: Situation analysis. Cellulose 16, 599-619.

Hirano, A., Hon-Nami, K., Kunito, S., Hada, M., and Ogushi, Y., 1998. Temperature effect on continuous gasification of microalgal biomass: theoretical yield of methanol production and its energy balance. Catalysis Today 45, 399-404.

Hu, Q., Sommerfeld, M., Jarvis, E., Ghirardi, M., Posewitz, M., Seibert, M., and Darzins, A., 2008. Microalgal triacylglycerols as feedstocks for biofuel production: perspectives and advances. The Plant Journal 54, 621-639.

Kim, H., Hahm, T., and Min, D., 2007. Hydroperoxide as a Prooxidant in the Oxidative Stability of Soybean Oil. Journal of the American Oil Chemists' Society 84, 349-355.

Kiritsakis, A. and Dugan, L., 1985. Studies in photooxidation of olive oil. Journal of the American Oil Chemists' Society 62, 892-896. 
Knuckey, R. M., Brown, M. R., Robert, R., and Frampton, D. M. F., 2006. Production of microalgal concentrates by flocculation and their assessment as aquaculture feeds. Aquacultural Engineering 35, 300-313.

López Barreiro, D., Prins, W., Ronsse, F., and Brilman, W., 2013. Hydrothermal liquefaction (HTL) of microalgae for biofuel production: State of the art review and future prospects. Biomass and Bioenergy.

Lundquist, T. J., Woertz, I. C., Quinn, N. W. T., and Benemann, J. R., 2010. A Realistic Technology and Engineering Assessment of Algae Biofuel Production. Energy Biosciences Institute, University of California, Berkeley, California.

Lung, S. and Weselake, R. J., 2006. Diacylglycerol acyltransferase: A key mediator of plant triacylglycerol synthesis. Lipids 41, 1073-1088.

Mata, T. M., Martins, A. A., and Caetano, N. S., 2010. Microalgae for biodiesel production and other applications: A review. Renewable \& Sustainable Energy Reviews 14, 217-232.

McGarry, M. G., 1970. Alga flocculation with aluminium sulfate and polyelectrolytes. Water Pollution Control Federation 42, 191-201.

Miao, X., Wu, Q., and Yang, C., 2004. Fast pyrolysis of microalgae to produce renewable fuels. Journal of Analytical and Applied Pyrolysis 71, 855-863.

Min, D. B. and Boff, J. M., 2002. Chemistry and Reaction of Singlet Oxygen in Foods. Comprehensive Reviews in Food Science and Food Safety 1, 58-72.

Mohn, F. H., 1978. Improved technologies for the harvesting and processing of microalgae and their impact on production costs. Arch Hydrobiol, Beih Ergeb Limnol 1, 228-53.

Mohn, F. H., 1980. Experiences and strategies in the recovery of biomass from mass cultures of microalgae. In: Shelef, G., Soeder, C.J. (Ed.), Agae biomass. Elsevier, Amsterdam.

Molina-Grima, E., Acien-Fernandez, F. G., and Robles Medina, A., 2004. Downstream Processing of Cell-mass and Products. In: Richmond, A. (Ed.), Handbook of Microalgal Culture: Biotechnology and Applied Phycology. Blackwell Science, Ames, IA.

Molina-Grima, E., Robles-Medina, A., Giménez-Giménez, A., and Ibanez-González, M., 1996. Gram-scale purification of eicosapentaenoic acid (EPA, 20:5n-3) from wet Phaeodactylum tricornutum UTEX 640 biomass. Journal of Applied Phycology 8, 359-367.

Molina Grima, E., Belarbi, E. H., Acién Fernández, F. G., Robles Medina, A., and Chisti, Y., 2003. Recovery of microalgal biomass and metabolites: process options and economics. Biotechnology Advances 20, 491-515.

Mora-Gutierrez, A., Attaie, R., and Farrell, H. M., 2010. Lipid Oxidation in Algae Oil-in-Water Emulsions Stabilized by Bovine and Caprine Caseins. Journal of Agricultural and Food Chemistry 58, 5131-5139.

Mujumdar, A. S., 2006. Handbook of Industrial Drying. CRC Press, New York, NY.

Oh, H.-M., Lee, S. J., Park, M.-H., Kim, H.-S., Kim, H.-C., Yoon, J.-H., Kwon, G.-S., and Yoon, B.-D., 2001. Harvesting of Chlorella vulgaris using a bioflocculant from Paenibacillus sp. AM49. Biotechnology Letters 23, 1229-1234.

Park, Y., Jeong, M., Park, C., and Lee, J., 2011. Distribution of Triacylglycerols and Fatty Acids in Soybean Oil with Thermal Oxidation and Methylene Blue Photosensitization. Journal of the American Oil Chemists' Society 88, 373-380.

Pienkos, P. T., 2013. Sustainable Algal Biofuels Consortium Project Update. NREL. 
Pienkos, P. T. and Darzins, A., 2009. The promise and challenges of microalgal-derived biofuels. Biofuels Bioproducts \& Biorefining-Biofpr 3, 431-440.

Putt, R., 2007. Algae as a Biodiesel Feedstock: A Feasibility Assessment. Center for Microfibrous Materials Manufacturing $\left(\mathrm{CM}^{3}\right)$, Department of Chemical Engineering, Auburn University, Alabama.

Rieper-Kirchner, M., 1990. Macroalgal decomposition: Laboratory studies with particular regard to microorganisms and meiofauna. Helgoland Marine Research 44, 397-410.

Roessler, P. G., 1988. Effects of silicon deficiency on lipid composition and metabolism in the diatom Cyclotella cryptica. J Phycol 24, 394-400.

Sheehan, J., Camobreco, V., Duffield, J., Shapouri, H., Graboski, M., and Tyson, K. S., 2000. An Overview of Biodiesel and Petroleum Diesel Life Cycles. National Renewable Energy Laboratory.

Sheehan, J., Dunahay, T. G., Benemann, J. R., Roessler, P. G., and Weissmann, J. C., 1998. A Look Back at the U.S. Department of Energy's Aquatic Species Program-Biodiesel from Algae. National Renewable Energy Laboratory.

Shelef, G., Sukenik, A., and Green, M., 1984. Microalgae Harvesting and Processing: A Literature Review. Technion Research and Development Foundation Ltd., Haifa, Israel.

Shirffrin, N. S. and Chisholm, S. W., 1981. Phytoplankton lipids: interspecific differences and effects of nitrate, silicate and light-dark cycle. Journal of Phycology 17, 374-384.

Snowman, J. W., 1996. Lyophilization. In: Verral, M. S. (Ed.), Downstream processing of natural products. A practical handbook. John Wiley \& Sons.

Sukenik, A., Cameli, Y., and Berner, T., 1989. Regulation of fatty acid composition by irradiance level in the eustigmatophyte Nannochloropsis sp. Journal of Phycology 25, 686-692.

Tornabene, T. G., Ben-Amotz, A., and Hubbard, J. S., 1982. Isolation, analysis and indentification of lipidsSERI ASP Report

Tornabene, T. G., Holzer, G., Lien, S., and Burris, N., 1983. Lipid composition of the nitrogen starved green alga Neochloris oleoabundans. Enzyme Microb Technol 5, 435-440.

Venkataraman, L. V., 1978. New possibility for microalgae production and utilisation in India.. Arch Hydrobiol Beih 11, 199-210.

Wang, B., Li, Y. Q., Wu, N., and Lan, C. Q., 2008. $\mathrm{CO}_{2}$ bio-mitigation using microalgae. Applied Microbiology and Biotechnology 79, 707-718.

Weissman, J. C. and Goebel, R. P., 1987. Design and analysis of microalgal open pond systems for the purpose of producing fuels: A subcontract report.

Wigmosta, M. S., Coleman, A. M., Skaggs, R. J., Huesemann, M. H., and Lane, L. J., 2011. National microalgae biofuel production potential and resource demand. Water Resour. Res. 47, W00H04, 13p.

Xu, L., Brilman, D. W. F., Withag, J. A. M., Brem, G., and Kersten, S., 2011. Assessment of a dry and a wet route for the production of biofuels from microalgae: Energy balance analysis. Bioresource Technology 102, 5113-5122. 